\title{
THE INCIDENCE OF RICKETS IN WAR-TIME *
}

\author{
BY
}

\author{
THE BRITISH PAEDIATRIC ASSOCIATION
}

\section{Introduction}

In 1942 the Minister of Health appointed an Advisory Committee on Mothers and Young Children. A Medical and Prófessional Sub-Committee $\dagger$ of this body was asked 'to consider the evidence available as to the war-time incidence of rickets, and the need for, and practicability of, any further preventive measures.' This Sub-Committee reported that although in certain parts of the country impressions had been formed that there was an increase in rickets, no scientific evidence was forthcoming to indicate that the disease was more or less prevalent than before the war. It was therefore recommended that an enquiry should be made into this important subject. Preliminary discussion had indicated that the British Paediatric Association was prepared to carry out an investigation in certain areas. Further deliberations were undertaken regarding the details of the investigation and agreement was finally reached on the procedure to be followed.

\section{Present survey}

A combined clinical and radiological investigation was planned to take place in the six weeks midJanuary to the end of February, 1943, in twentythree areas of Great Britain and Ireland. It was unfortunate for the investigation that the period chosen was exceptionally fine and sunny and that the whole winter had been mild. A questionnaire was drawn up and approved by Dr. Percy Stocks, Medical Statistician to the General Register Office and to the Ministry of Health. A letter was addressed by Sir Wilson Jameson, Chief Medical Officer, Ministry of Health, to the Medical Officers of Health of those areas (18) in England and Wales in which the investigation was taking place, asking for their co-operation with the paediatricians concerned. A grant was made by the Ministry of Health to cover the expenses of the investigation in England and Wales. The Secretary of State for Scotland was associated with these arrangements and, with the concurrence of his Scientific Advisory

* This report was published as No. 92 of ' Reports on Public Health and Medical Subjects,' by the Ministry of Health. It is reproduced by kind permission of the Controller, H.M. Stationery Office. Certain portions have been omitted in this version such as a prefatory note and a list of acknowledgments.

$\dagger$ The composition of this Sub-Committee is as follows:Dr. Alan Moncrieff (Chairman), Miss Calder, Dr. Ethel Cassie Miss Coni, Dr. W. S. Macdonald, Dr. C. M. Smith, Mr. Arnold Walker, Dr. Edith Williamson, Dr. D. H. Geffen (who joined the Sub-Committee in July, 1943) and Dr. G. I. Brodie (Secretary).

F
Committee, the enquiries by the British Paediatric Association extended to Glasgow, Edinburgh and Aberdeen. The Department of Health made a financial grant in respect of the cost of $x$-rays and other expenses incurred in the prosecution of the enquiries in Edinburgh and Aberdeen. In Glasgow the cost was borne by the Corporation. In Belfast the voluntary hospital undertook the x-ray examinations and in Dublin the investigation was sponsored by the Dietetic Council. In many districts in all parts of Great Britain the cost was borne by the voluntary hospitals or local authority. Certain areas were selected, partly because there was a member of the British Paediatric Association available and partly because in some of the areas a pre-war investigation on similar lines had been undertaken and was available for comparison.

The details of the investigation, as set out in a letter to all those taking part, were as follows:-

The age of the children was to be 3 months to 18 months and each member was asked to secure a minimum of 200 observations if possible in his area. The method of selecting children was left for local arrangement, certain alternatives being suggested:-

(a) Children attending hospital or in-patients suffering from minor ailments or accidents.

(b) Children attending Welfare Centres.

(c) Children in war-time Nurseries.

(d) Children of the age group mentioned, selected by taking every tenth, fiftieth or some such number card from the Notification of Births Register.

(e) According to any plan used in the same area for a previous investigation of rickets.

Details of the areas and methods of selection are set out in the table in Appendix 1.

Local authorities were asked, as already mentioned, to co-operate, and incidental expenses (fares for mothers and children, cost of x-ray examinations) were allowed. An x-ray of one wrist was taken on each child and a clinical examination made by, or under the direct supervision of, the paediatrician concerned. The reading of the x-rays was carried out by a radiological committee consisting of Dr. S. Whately Davidson (Newcastle), Dr. D. C. Suttie (Glasgow) and Dr. C. G. Teall (Birmingham). A questionnaire to be completed for every child was drawn up and a specimen is reproduced in Appendix 2.

The paediatricians taking part were invited to elaborate the investigation in any way they wished, 
provided facilities were available and any additional costs involved were met locally. The chemical diagnosis of rickets, for example, by means of estimating the blood calcium, phosphorus and phosphatase, was one extension which it was hoped would be undertaken when possible: the incidence of scurvy in the children under review was another point to which attention was directed. The questionnaire was designed to record not only the clinical and radiological findings upon which a diagnosis was based but also certain data regarding feeding and the prophylaxis of rickets. Detailed statistical analysis of the answers was undertaken by the Statistical Department of the General Register Office under Dr. Percy Stocks, and his report is set out in full on pages 48-62.

Lime content of the soil. The investigators were asked in each centre to furnish particulars of the lime content of the soil and this was done in some detail in certain areas, as, for example, the report from Lincolnshire quoted in full. But for the most part it was clear that the soil of the areas in question did not necessarily have anything to do with the water supply nor with the probable calcium intake of the diet of the children under investigation. Therefore, although in some areas great trouble was taken to supply details, they are not included in this report as they are essentially misleading.

Blood chemistry. In some areas determinations from samples of blood of the calcium, phosphorus and phosphatase content were made. There are obvious practical difficulties in a voluntary survey involving small infants in obtaining the necessary relatively large amounts of blood required so that only in exceptional instances was it possible to carry out this important part of the investigation. It is hoped that the results obtained will be published elsewhere.

\section{Previous investigations}

There have been many surveys of rickets in this country but few only with strict radiological control. The following have been selected because the 1943 investigation was also carried out in these areas.

LoNDON. Paterson and Darby (1926) studied the incidence of rickets by radiographs in 339 children aged a few weeks to 2 years, attending the Infants' Hospital and the Children's Department of St. Thomas' Hospital, London, as new patients in February, March and April, 1925. Of these

4 showed active rickets $-1 \cdot 2$ per cent.

110 showed healed rickets- 32 per cent.

Atkinson and others (1926) studied the subject in the same way at a hospital serving a poor district in the East End of London during April, 1925. $\mathrm{X}$-ray of the wrist in 169 children, mostly new patients attending the casualty department for the first time, between the ages of one week and 2 years, indicated rickets in 8 per cent., mostly of slight degree. (Mackay, commenting on these results (1926) thinks that radiology underestimates the incidence of rickets which clinical examination would probably indicate as twice as prevalent as when revealed by $\mathrm{x}$-rays.)

MANCHESTER. Chisholm (1933) investigated 1600 unselected children (not attending infant welfare centres) in Manchester during a period of two years. The children were aged 6 to 24 months and x-ray investigation showed $7 \cdot 3$ per cent. with definite evidence of recent rickets, active, healing or lately healed. A further 21 per cent. were 'suggestive of slight rickets.' The monthly charts showed a peak in May. Chisholm refers to a previous investigation in 1926 when 26 per cent. of a small group of unselected children had shown active rickets.

NewCastle-ON-TyNe. Spence (1934) from X-ray evidence of groups of children. between the ages of 1 and 5 years, during 'a summer of exceptional sunshine 'found 5 out of 103 between the ages of 1 and 5 years with active rickets of a severe degree (4.9 per cent.). In a further 16 children recent rickets of a very mild degree was reported. Brewis, Davison and Miller (1939) studied a similar group of children during the winter of 1938 to 1939 . In none of the 138 children examined was there radiological evidence of rickets, active or healed.

GLASGOW. Graham (1942) examined a series of 300 consecutive children admitted to hospital over a period of twelve months in 1940-41. They were all under 18 months of age and certain very ill children were omitted. Clinically 76 out of 269 gave positive evidence of rickets $(28.3$ per cent.) and radiologically 49 out of 208 were positive for rickets (23.6 per cent.).

\section{REFERENCES}

Atkinson, W. P. T., and others. (1926). Arch. Dis. Childh., 1, 30.

Brewis, E. G., Davison, G., and Miller, F. J. W. (1939). - Investigation into the Health and Nutrition of the Children of Newcastle-upon-Tyne between the ages of one and five years.' (Special Report published by the Newcastle Corporation Health Department.)

Chisholm, C. (1933). Brit. J. Child., Dis. 30, 83.

Graham, S. (1942). Arch. Dis., Childh. 17, 167.

Mackay, H. M. M. (1926). Ibid., 1, 30.

Paterson, D., and Darby, R. Loc. cit., 36.

Spence, J. C.'(1934). 'Investigation into the Health and Nutrition of the Children of Newcastle-upon-Tyne between the ages of one and five years.' (Special Report published by the Newcastle Corporation Health Department.) 


\title{
SURVEY OF RICKETS IN LINCOLNSHIRE (PARTS OF KESTEVEN) *
}

\author{
RICHARD W. B. ELLIS, M.D., F.R.C.P., AND AUDREY E. ELLIS, M.B., B.S.
}

The area chosen for the present survey was that within an eight-mile radius of Sleaford, a small market town with a pre-war population of $7405 . \dagger$ It is normally one of the most completely rural areas in the country, and although the population has materially altered since the war owing to the influx of R.A.F. personnel and families, the standard of living in the villages has probably changed as little as anywhere in England. Sleaford lies between the rich, low-lying ' fen' land on the east and the rising ' heath' land on the west. The exact lime content of the surface soil varies greatly from village to village and even from farm to farm, but the heath area coincides with a superficial out-crop of Lincolnshire limestone $\ddagger$ and the underlying formation in both heath and fen is almost entirely oolitic (i.e. limestone) in the area surveyed (see Appendix 3). As the water supply on the heath and in much of the fen is derived from artesian wells, the drinking water throughout most of the district has an exceptionally high calcium content.

The only area included in the survey in which there is any approach to urban conditions is the urban district of Sleaford itself. It was therefore decided to draw approximately one-third (66) of the 200 babies examined from Sleaford, and remaining 134 from surrounding villages. Half of these villages lie in the fen or fen border and half on the heath. Altogether twenty villages and hamlets were selected, the aim being where possible to examine all the babies of the age group (3-18 months) in the village. In nine villages (listed as ' $C$ ') the complete age group was in fact surveyed, with the exception of those who were unable to attend for x-ray on account of illness. (Thus in Ruskington, one of the largest villages included, only 24 out of a possible 32 babies attended owing to an epidemic of whooping cough.) In most villages there was little difficulty in obtaining a nominal roll of eligible babies either from the district nurse, health visitor, or by domiciliary visits. The following villages were sampled or completely surveyed (' $\mathrm{C}$ '):

FEN AND FEN BORDER VILLAGES

Anwick

Digby (C)

Dorrington (C)

Great Hale

Heckington

Helpringham

Kirby Green (C)

Rowston (C)

Ruskington (C)

Scopwick

HEATH VILLAGES

Ancaster

Ashby-de-la-Launde (C)

Brauncewell

Creanwell (C)

Fulbeck

Leasingham

Rauceby (C)

Scredington

Sudbrook

Wilsford (C)

\footnotetext{
* Although in general observers did not submit detailed reports it is considered that this report is of special interest in showing how the investigations were conducted and difficulties overcome.

$\dagger$ Annual Report of the County Medical Officer of Health, Kesteven County Council, 1938.

$\ddagger$ The Land of Britain. The Report of the Land Utilization \$ The Land of Britain. The Report of the Land
Survey of Britain. Part 76-77 by L. Dudley Stamp, 1942.
}

In Sleaford, owing to the considerable floating population, it was felt that no method of sampling from the birth register could be regarded as completely satisfactory. A nucleus of names was therefore obtained from the Welfare Centre, from one of the free churches, from the nearest R.A.F. station, and through the Red Cross, and domiciliary visits were made in two areas of council houses, and in one of the oldest streets in the town. Although the present population figure of the town is not available, it is clear from the amount of overlap of the various lists that the number of babies examined represents a substantial portion of the eligible age group. The results of the survey as regards the incidence of rickets are summarized in the Statistical Section by Dr. Stocks.

In order to ascertain if there were any outstanding differences between the Sleaford group and the ' rural' groups of babies, which might be expected to influence the incidence of rickets, an enquiry was made in each case with regard to (1) size of family, (2) father's occupation (as a rough index to family income), (3) illnesses, and (4) whether the household had a vegetable garden. The last was considered important not only as providing a place where the baby could be put out of doors but also from the effect of home-grown vegetables upon the family diet and budget. It was realized too late in the survey that another useful enquiry would have been as to whether hens were kept, since it was found that a number of the older babies in the rural group were getting an egg a day whereas in Sleaford one egg in four or five weeks was a common finding. These enquiries showed a higher proportion of first babies in the Sleaford group, but on the whole the difference in size of family in the two groups is doubtfully significant. Thus in the Sleaford group 56 per cent. were first babies, 20 per cent. second babies, 9 per cent. third and 7.5 per cent. fourth babies, with $7 \cdot 5$ per cent. from families of 5 or more children. The corresponding figures for the rural group were 46.5 per cent. first babies, 23.5 per cent. second, 17 per cent. third, 4 per cent. fourth, and 9 per cent. from families of 5 or more children.

In the rural group, 94 per cent. had gardens and grew their own vegetables, as compared with 75 per cent. in the Sleaford group. As, however, there are no large blocks of flats in Sleaford and the great majority of houses are of not more than two stories, there are few, if any, babies even in the Sleaford group who could not be out of doors easily if desired.

The incidence of illnesses in both groups was comparable, though as a number of babies had to be excluded from the survey on account of pertussis, too much stress cannot be laid on the actual figures. Seventy per cent. of the Sleaford babies and seventysix per cent. of the rural babies had been free from 
all illnesses except colds; the general nutrition of both groups was good. (An interesting irrelevance was discovered in a pair of identical twins who had both developed pyloric stenosis, confirmed at operation; comparison of the x-rays shows almost identical lines of arrested growth.)

Analysis of the father's occupation showed that unemployment was negligible in both groups, only one father being unemployed owing to invalidism; five rural and four Sleaford babies were known to be illegitimate. The only major difference in the two groups was, as would be expected, that a much higher proportion of fathers in the Sleaford group were serving in the forces (67 per cent.) as compared with 38 per cent. in the rural group, whilst the rural group contained 32 per cent. agricultural workers as compared with 6 per cent. in Sleaford. Only one factory worker was included in the whole series.

Taking into consideration the small size and character of Sleaford and the absence of smoke pall, it is therefore considered that all the 200 babies included in the survey should be regarded as coming from an essentially rural area, and that as such they form a true basis of comparison with groups drawn from urban areas.

Owing to the isolated position of many of the villages and the fact that the only $x$-ray apparatus in the district was at a Service hospital where examination had to be made in the evenings, it was necessary not only to provide transport for almost every one of the 200 babies, but also to carry out the majority of the x-ray examinations during the latter part of February in order to avoid 'black-out' hours. Since February this year (1943) has been exceptionally fine and sunny, it is probable that the incidence of active rickets will be lower than in previous years. On the other hand, a survey of this type would have been virtually impossible in this area during January and February for the past three years owing to the state of the roads. Even when special buses were sent to collecting points, many of the mothers had to carry their babies considerable distances over field paths to reach the hospital. It was most gratifying to find the interest and co-operation shown both by the mothers, district nurses, and health visitors in the survey.

\section{Clinical diagnosis of rickets *}

Before the results of this investigation are given it is important to indicate some of the main points upon which a clinical diagnosis of rickets may be based. Rickets may be defined as a metabolic or nutritional disorder characterised by imperfect calcification of growing bone. Diagnosis, therefore, depends upon detecting imperfectly calcified bone, i.e. bone which is soft or which shows a heaping up of osteoid tissue at the site of growth. The four situations chosen in the investigation were the skull, the costo-chondral junctions, the wrists and the teeth. The legs were excluded because enlargement of the epiphyses in the lower limbs is more difficult to detect except in gross rickets and the same consideration applies to changes in the vertebral column. Bowing of the legs is often regarded as due to rickets, but this is only the case when the bowing is due to actual curvature of the bones. In the young infant under three months the 'foetal position' with crossed legs is still persistent and gives an appearance of bowing. Real bending of the bones is only seen nowadays with severe rickets, lasting a long time so that the child is walking upon softened bones. Again, the muscular development of the legs of the young toddler often makes the legs appear to be bowed, an appearance which is often mistakenly regarded as due to rickets. X-ray examination in such cases shows perfectly straight bones, the curvature being entirely due to the soft parts of the limbs.

With regard to the four situations chosen for examination it must be realized that the maximum change found varies with the age of the child. It is the demands of the growing bone for calcium phosphate that determine whether or not rickets will be produced. The rate of growth is at its maximum in the earlier periods of infancy and childhood and it

* Unless otherwise indicated, all unsigned sections of this report are the responsibility of the British Paediatric Association. is during these periods of maximum demand that a shortage is most likely to be found. At any period the greatest amount of bony change is found at the site of maximum rate of growth at that period. At the younger ages the skull is growing most rapidly and therefore cranio-tabes is a valuable sign at the age of three or four months. At about six months enlargement of the costo-chondral junctions is the most prominent sign and later in the first year the enlargement of the epiphyses at the wrists dominates the picture. In this investigation only the wrist was examined radiologically and it is possible that a baby with mild rickets could show definite clinical changes in the skull or at the costo-chondral juntions with only minimal changes in the $\mathrm{x}$-ray picture of the wrist. Some disparity between the clinical and radiological findings may be explained along these lines.

There is, however, another reason why clinical diagnosis shows variations and disparities as compared with the radiological findings. What is termed ' enlargement' of the costo-chondral junctions and the epiphyses at the wrists presupposes that there is a normal ' size ' in these situations which the examining physician can keep in his mind as a standard: only when he considers that the standard has been exceeded does he record this as an ' enlargement.' It follows that there must be a large subjective element in clinical diagnosis based on such changes and there will be more errors-both of over-diagnosis and of under-diagnosis-the less the experience of the examiner. When severe rickets was common the same difficulty scarcely arose because severe rickets is easy to diagnose by the gross bony changes. Such severe cases are now rare and in any case the investigation was designed to provide for the examination of large numbers of essentially healthy children in whom ricketty changes were likely to be minimal rather than maximal. 
With regard to cranio-tabes another difficulty arises. Softening of the bones of the skull, due to rickets, certainly may produce the characteristic soft areas in the occipital region in the three or four months' old baby. Many observers have come to believe that in a rapidly growing healthy child of this age, with a rapidly growing brain, some degree of softening may for brief periods be found in the same regions and that the future development of such children does not support the view that there has been any radical disturbance of calcium and phosphorus metabolism at the earlier period. To such findings the term 'physiological' rickets has been applied.

Delay in closure of the anterior fontanelle is a more reliable sign of rickets but it is only of value in the later periods of infancy since normal closure does not occur until the eighteenth month. Delay in the appearance of the teeth is subject to much variation among the healthy, normal child population and as a sign in rickets delayed dentition in a gross enough form to be significant is also likely to be a late sign. With the milder type of rickets now seen the slowing down of the rate of growth during the second year of life generally means that calcification begins to proceed normally. In other words the rickets heals unless the nutritional defect is gross and continued. These late signs therefore lose their value.

Before the etiology of rickets was fully understood certain signs and symptoms were attributed to rickets which are now more satisfactorily allotted to associated nutritional deficiencies. For example, the pallor and anaemia are better explained by an associated iron deficiency. Recurrent infections of the respiratory and alimentary systems may be better explained as due to a lack of vitamin A. There remains for consideration nervous instability, sweating of the head and muscular hypotonia (responsible for the pot-belly and for delay in walking). All these manifestations are more common in the severe type of rickets and in the milder types are too variable and too likely to be subject to individual judgments to be of value in reaching a firm clinical diagnosis. The pale and flabby baby is not necessarily suffering from rickets. Indeed it is a curious paradox that if under-nutrition in general terms is severe enough to stop growth then rickets is unlikely to be present. The well-known phrase ' no growth, no rickets' means that only when the growing bones make unsatisfied demands for calcium phosphate do the changes of imperfect calcification, i.e. rickets, appear.

To sum up it may be said that in the severe types the clinical diagnosis of rickets is usually easy, in the milder forms extremely difficult and in the minor degrees of bony change quite impossible. For these reasons radiological diagnosis becomes of increasing importance as the disease gets milder, and in the mildest type even radiological examination of the wrists of a baby under six months may fail to show changes which clinically appear fairly obvious in the skull or at the rib junctions. It is against this background of clinical difficulty that the results analysed by Dr. Stocks should be judged.

\section{The radiological diagnosis of rickets}

Radiography is of great value in the diagnosis of rickets, especially in the early and mild forms of the disease. It is not proposed to set out the detailed points which guide the radiologist in making his diagnosis, for these have obviously an individual significance and it must be emphasized that there is just as much a subjective influence in the radiologist's opinion as in that of the clinical observer.

For the purpose of establishing the diagnosis, the anterior end of the ribs should, on account of their structure, supply the earliest radiographic evidence, and in post-mortem specimens this is readily demonstrated. Unfortunately, however, the situation of the ribs does not lend itself to a sufficiently accurate examination. In the skull evidence of cranio-tabes is held to be of value in the diagnosis of rickets, but the radiological appearances are seldom as obvious as those found on clinical examination. In practice, therefore, the distal, more rapidly growing ends of the fore-arm bones are chosen for examination, for the reason that they are superficially placed and not obscured by overlying tissues and can be examined with a reasonable chance of success, even in a fretful, ill child. Just how tiresome a child with rickets can be from the radiologist's point of view, only those who have had to examine these children know. Considerable patience is required, for good films are essential in order to demonstrate the early signs of the disease. Correct positioning with the wrist in full supination is equally important, for one of the signs of rickets, cupping of the bone end, may easily be simulated by making the radiograph with the fore-arm in even a slight degree of pronation.

Another preliminary consideration is that although the earliest radiological signs would be found in the ribs, if these were accessible, it is reasonable to suppose that in a routine examination, which consists of examining the wrists, a number of cases in the very early stage of the disease may be overlooked, but it is believed that this number is small. It is also true that there are a few cases in which the pathologist is able to demonstrate the presence of rickets at post-mortem examination, when first-class skiagrams have failed to show any evidence of rachitic changes during life. But in these cases there is no clinical evidence of rickets, and on the other hand cases which have been diagnosed on clinical grounds as rickets may show no radiological evidence of the disease. Beading of the ribs, for example, is not necessarily associated with any radiological evidence that confirms the diagnosis of rickets.

Active rickets. From what has been said it is clear that there must be a stage in which the condition is present without demonstrable radiographic changes. The earliest sign for practical purposes is irregularity and loss of definition of the lower end of the bone shaft, which is normally smooth. The degree and extent of the changes depend partly on the activity 
of the rachitic process and partly on the rate of growth of the bone in the period preceding the x-ray examination. Cupping with definite frayed edges extending out towards the epiphysis is often better seen in the ulna than in the radius (but correct positioning is essential). In well-nourished infants with rapid growth the typical concave or torch-like end of the diaphysis is seen. As the disease progresses changes may also be observed in the shafts of the bone, esentially those of a diminution in density. Various detailed descriptions of these changes have been given elsewhere in the relevant literature, but every radiologist has his own standards.

Healing rickets. The first change seen is a more or less linear shadow in the cartilaginous zone at the end of the diaphysis and it corresponds to the beginning of calcification in the mass of osteoid tissue.
Healed rickets. Normal shadows at the ends of the diaphysis have now appeared, but the new bone often shows coarse trabeculation for some time. The shafts resume their normal density.

From these radiological descriptions it will be realized that border-lines between 'active' and ' healing' are very likely to be present. Indeed it is possible to find early healing changes in the end of the ulna when those of the radius still correspond to activity. It must also be remembered that the appearances in healed rickets have some resemblance to those changes seen after periods of severe malnutrition, pneumonia, the exanthemata and anaemia. Here the clinical history would normally be a guide to the radiologist. In the present survey radiological opinions were given on the films alone. The mass of radiological material collected in this survey would well merit a more detailed examination from many aspects.

\title{
STATISTICAL ANALYSIS
}

\author{
BY \\ PERCY STOCKS, M.D., D.P.H.,

\section{Medical Statistician to the General Register Office and Ministry of Health}

\section{I.-Incidence of radiological rickets in children}

The number of children for whom x-ray films and reports were available for analysis was 5283, examined at the following centres:-

\section{Northern towns of England}

Newcastle-on-Tyne 218; Manchester 218; Leeds 146; Sheffield 141; Liverpool 283.

\section{London County}

Hackney 347; Hammersmith 217; Holborn 118; Westminster 158.

\section{Birmingham 484 .}

\section{Other areas in England and Wales}

Bristol 242; Cardiff 269; Leicester 96; Aylesbury 77; St. Albans 200; Watford 150; Lincolnshire 200; Warwickshire 210.

\section{Scottish towns}

Aberdeen 319; Edinburgh 220; Glasgow 700.

\section{Irish towns}

\section{Belfast 71; Dublin 199.}

The children were for the most part between 3 and 18 months of age, but 11 were under 3 months and 198 were between 18 months and $3 \frac{1}{2}$ years (see Appendix A). For 3 the records were insufficient and they have been omitted. It was at once evident that the incidence of radiological rickets was so dependent on age that no useful information could be obtained without age-grouping; consequently the children were separated into 5 divisions of age at the time of examination, viz. 3-6 (i.e. 3 months but not yet 6 months of age), 6-9, 9-12, 12-15 and 15-18 months.

Each x-ray film was examined by three radiologists (the same specialists throughout) and a diagnosis of radiological rickets was based on the opinion of at least two. The radiologists were asked to answer yes or no to the question whether the film showed that rickets was present or not, and if present whether it was ' active ' or 'old (healed).' In order to measure the rate of incidence of rickets in the child population from data obtained by instantaneous samples, mere percentages of children showing active rickets at different ages will tell us little unless it is known what is the average duration in time of the active stace (that is to say the average time elapsing from the moment at which $x$-ray signs become recognizable to the moment at which they take on the appearance of ' healed' rickets or alternatively disappear). Suppose, for example, that - it is desired to find what proportion of children suffer from diphtheria during their first year of life by counting at an instant of time how many out of 10,000 children are actually ill with diphtheria, and suppose that 2 are found; the proportion required is not 2 per 10,000 but probably 12 times that rate because the average duration of the illness is about one-twelfth of a year. Similarly if 4 per cent. of 
children under 1 year of age are found to show signs of active rickets at a given moment, this tells us nothing about the proportion who are developing rickets during their first year of life except that it must be at least 4 per cent. If the average duration of the active phase (radiologically recognizable as such) is six months, the incidence of rickets during the first year of life will be about $4 \times 12 / 6=8$ per cent., or if the duration averages 4 months the incidence will be about $4 \times 12 / 4=12$ per cent. The duration of active rickets may depend upon the speed of its recognition and efficiency of treatment, and the average may vary in different parts of Britain.

In the present investigation it is desired to find out what proportions of children in different towns are developing rickets before a given age, or between given ages. If an attack of rickets always left permanent radiological signs of healed rickets behind it, this could be done by finding the proportions of children at the age or ages in question who show radiological signs of rickets, either active or healed. That signs of healed rickets may not persist for long under present methods of treatment is suggested by the fact that in the group of Northern towns of England, which is by no means free from rickets at ages 3-9 months, not a single child with radiological signs of healed rickets was recorded at ages 12-18 months. Nevertheless, the total proportion showing active and healed rickets at ages centred at 6 months gives a minimal measure of the rate of incidence up to that age, though it may be rather below the true rate owing to the disappearance of signs in mild cases when the active stage has terminated. At later ages this method is not applicable, partly because of this disappearance of signs and also because under present conditions it can hardly be assumed that the conditions responsible for the development of rickets have remained constant over as much as a year. The rates of incidence between 6 and 12 months and between 12 and 18 months must be deduced from the proportions showing active rickets in conjunction with an estimate of the average duration of the active stage.

It is necessary to assume, when estimating the rates of incidence in whole communities of children, that the samples examined were really taken out of the population without any selective bias which might tend to enhance or diminish the proportion with radiological signs of rickets. A certain degree of social and physical selection is involved in all surveys of children brought by parents or others to centres and clinics for examination or treatment, and the rates of incidence must be understood to refer to that section of the child population. It was implicit in the survey that no conscious selection was to be exercised in choosing the children to be examined out of those available, and there is no reason to suppose that this principle was departed from. The groups

$\begin{array}{lrrrrrr}\text { Month of age } & . & . & 3- & 4- & 5- & 6- \\ \text { No. examined } & . & . & 39 & 72 & 58 & 61 \\ \text { 'Active } . . & \ldots & \ldots & - & - & 1 & 2 \\ \text { Healed . } & . & . & - & 5 & 5 & 3 \\ \text { Per cent. active and healed } & 0 & 6 \cdot 9 & 10 \cdot 3 & 8 \cdot 2\end{array}$

of children drawn upon at different centres in order to ensure the necessary numbers must, however, have differed somewhat in kind from one town to another, and this may have influenced the comparative rates, though not it is believed to any serious extent. Comparisons between regional groups of towns are unlikely to have been appreciably affected by such variations in methods of finding the children, nor are the general conclusions reached from consideration of the whole material; but rates of incidence in individual towns should be considered with caution, both on the ground of the small numbers examined and because of such possible unconscious bias in some of the samples.

In the tables which follow, the numbers and percentages of the children examined who showed radiological signs of (1) active rickets and (2) either active or healed rickets are shown. The first measure comprisẹs children from whose $\mathrm{x}$-ray film of a wrist at least two of the three radiologists diagnosed ' active' rickets. This was not always easy to ascertain since in some instances one wrote ' healing,' another ' active,' and the third merely initialled 'Yes.' Full details of what was written are given, therefore, in Appendix B for all children classed as radiologically positive in the tables. For Belfast and Dublin no figures of active rickets alone have been given owing to this difficulty. The second measure comprises all children regarding whom at least two of the three radiologists answered 'Yes' to the question ' Rickets present,' such qualifications as ' probable,' ' mild,' 'slight,' being counted "as Yes. In some instances one radiologist gave no opinion on the ground that the photograph was not clear, and if the second answered ' Yes' and the third 'No' such children were classed as negative. Table 1 gives the total children examined, and the numbers and percentages radiologically positive according to each definition, at age periods 3-6, 6-9, 9-12, and 12-18 months in each centre, and Ap. pendix A gives the data for the 209 children whose ages fell outside 3-18 months. In table 2 the information in table 1 is condensed into regional groups and standard errors of the percentages are given. The Scottish and Irish children at 18-24 months of age are also included from Appendix A.

It is evident from table 1 that while Liverpool children showed no appreciable amount of rickets, in the other four towns in the North of England appreciable percentages showed radiological signs of active and healed rickets combined at ages under a year. Combining Manchester, Leeds, Sheffield and Newcastle (table 2) 6 out of 504 at ages of 3-12 months, or 1.2 per cent., showed active rickets, and the proportions with either active or healed rickets were 6.5 per cent. at 3-6 months, 8.9 per cent. at 6-9 months, $3 \cdot 8$ per cent. at 9-12 months and none at 12-18 months. The more detailed age distribution by months of age was as follows:-

$\begin{array}{cccccc}7- & 8- & 9- & 10- & 11- & 12-18 \\ 55 & 63 & 52 & 46 & 58 & 198 \\ 1 & \frac{2}{3} & \frac{2}{3 \cdot 8} & \frac{2}{2} & \frac{2}{-} \\ 7 & 4 \cdot 8 & 3 \cdot 8 & 4 \cdot 3 & 3 \cdot 4 & 0\end{array}$


The percentage of children who developed rickets in the first 6 months of life in this group of towns may be measured by the mean of the percentages at 5 and 6 months of age with signs of rickets, active or healed, namely, 9.2 per cent.; or if we take the mean of the 4, 5, 6 and 7 months old children (also centred at 6 months exactly) the percentage is 9.9. .The standard error of the first estimate is 2.6 and of the second 1.9 and it must be concluded that not less than 6 per cent. and probably as high a proportion as 9 or 10 per cent. of children born in these towns during the winter of 1942-43 developed rickets before 6 months of age, though in most instances it rapidly reached the stage of healing.

From the ratio of healed to active cases and the run of the figures above it appears that the average duration of the active stage (radiologically defined) must have been about 4 months, and since 1.5 per cent. of children between the ages of 6 and 12 months showed active rickets in the four towns, the incidence of fresh cases during that age period may be estimated as about 2 per cent. Between 10 and 18 months of age no children with active rickets were found amongst some 300 examined, but 4 at 10-12 months of age showed signs of healed rickets. The absence of healed rickets at 12-18 months might be due to conditions in the early part of 1942 having been less favourable to the development of rickets than in the winter of $1942-43$, or else to the disappearance of radiological signs by the time this age was reached.

Amongst the other towns of England and Wales, Bristol had 3 children at 3-6 months for whom two of the radiologists diagnosed probable or possible healed rickets (see Appendix B), and one with unmistakable signs at 9-12 months, but even when the first three are regarded as positive the calculated percentage developing rickets before 6 months of age is only 3 per cent. with a standard error of 1.7 , so it cannot be said with certainty that the incidence was above that in the Southern towns. The two Lincolnshire children were also considered somewhat doubtful. In Cardiff only one child with healed rickets was found out of 264. London gave indication of a rate of previous incidence around 6 months of age of about 1 per cent. with no active rickets observed at any age. In Birmingham the rate of incidence up to 9 months was about $2 \frac{1}{2}$ per cent. and no active rickets was found. Apart from the four Northern towns (Newcastle, Manchester,
Leeds and Sheffield), and perhaps Birmingham and Bristol, the incidence of rickets was, therefore, very small at the centres in England and Wales.

Of the Scottish towns Aberdeen gave a calculated incidence in the first 6 months of about 4 per cent. with standard error 1.8 ; and 5 out of 168 children aged 6-12 months or 3 per cent. showed active rickets. Glasgow showed about 2 per cent. developing rickets up to 6 months, and 3 out of 361 with active disease at 6-12 months. In Edinburgh no active rickets was found in 122 children at 3-9 months and only one child was observed with signs of healed rickets. In the Scottish towns as a whole the incidence of rickets up to 6 months of age was about 2 per cent.

The reports of the radiologists on the Irish children were so conflicting as to whether rickets was active or healed that no figures for active rickets have been entered in the tables (see details in Appendix B). In Belfast no less than 8 out of 28 children aged 3-9 months showed radiological signs, and according to one radiologist all of these were active whilst another considered 7 to be healing. At 9-18 months 5 out of 35 showed signs, of whom at least 3 were agreed to have active rickets. This indicates a much higher incidence than at any other centre. In Dublin 7 out of 92 children aged 3-9 months showed radiological signs ( 3 being active according to one radiologist), and the incidence up to 6 months seems to be similar to that in the group of four Northern English towns. At 12-18 months 5 out of 58 children showed signs ( 3 active according to one radiologist), this continued high incidence after 1 year of age being in contrast with English and Scottish towns.

The sex ratio amongst the 90 radiologically positive children aged 3-12 months did not differ significantly from that of 3414 radiologically negative children, as shown in the table on this page.

At ages 12-18 months the 16 positive children comprised 10 boys and 6 girls, whilst the 1551 negative children comprised 823 boys and 728 girls. At all ages 3-18 months just half of the positive children were boys. The incidence of radiological rickets was not, therefore, significantly different in the two sexes.

Radiological surveys of children prior to the war were for the most part not comparable with the present one, either because they dealt with older children or because the children were hospital

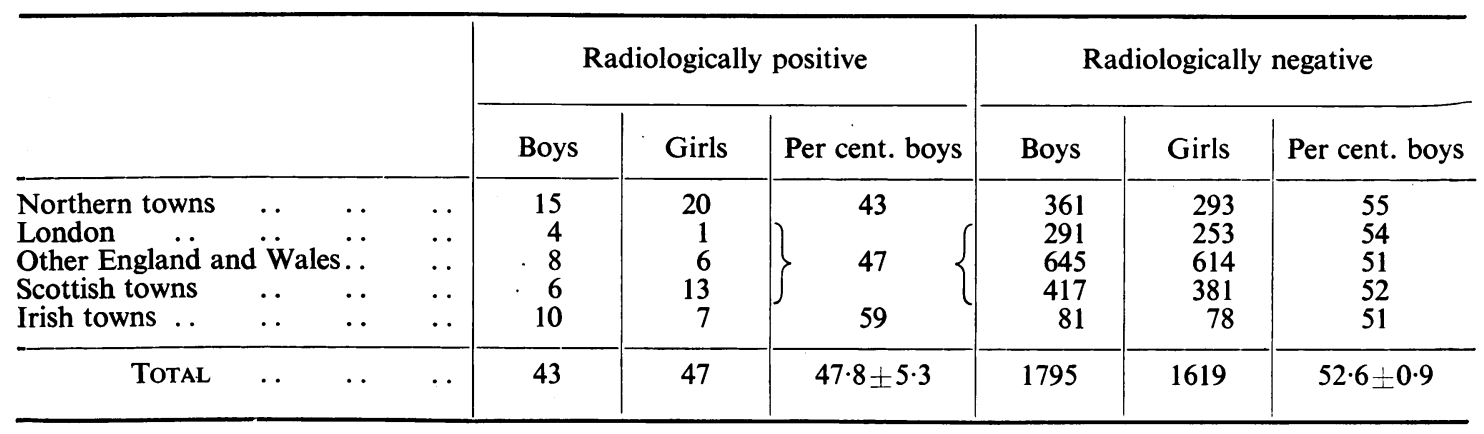


patients and not representative of the general population. Chisholm's study of unselected children aged 6-24 months attending Manchester infant welfare centres, reported in 1933, showed about 7 per cent. with definite radiological signs and another 21 per cent. with signs suggestive of slight rickets. These figures may be compared with the Manchester rate in the present survey of 5 with radiological signs out of 178 at ages 6-18 months or about 3 per cent. The surveys of Newcastle-onTyne children in 1934 and 1939 were confined to ages 1-5 years, and in the latter year no radiological signs were found amongst 138 children of those ages. In the present study 18 out of 165 under 1 year of age showed signs, but none out of 53 between 1 and 2 years of age. These scanty data available for comparison provide no evidence, therefore, of any war-time increase in the incidence of radiological rickets.

\section{Summary of Section I}

At 18 centres in England and Wales, 3 in Scotland and 2 in Ireland, 5071 children aged 3-18 months and 209 at other ages were surveyed. X-ray photographs of their wrists were examined by three radiologists without knowledge of the clinical findings. There was a fair measure of agreement as to the presence or absence of radiological signs believed to indicate rickets, but poor agreement as to whether the condition was active or healed, particularly with respect to the Irish children. The majority opinion was taken where there was disagreement.

In Great Britain, out of 3328 children aged 3-12 months, 17 showed ' active' and 56 healed or healing rickets; and out of 1490 aged 12-18 months there were 3 ' active' and 7 healed. The rate of incidence of rickets, radiologically defined, was estimated as $2 \frac{1}{2}$ per cent. before 6 months of age and 4 per cent. during the first year of life. Of the 73 children aged 3-12 months showing radiological signs, 33 were found (amongst a total of 504 examined) in Newcastle-on-Tyne, Manchester, Leeds and Sheffield. The rate of incidence before 1 year of age in this group of towns was 10 to 12 per cent., but no radiological signs of rickets were found amongst 198 children aged 12-18 months. No other area in Great Britain gave a first-year incidence exceeding 2 or 3 per cent., but in Dublin children it was over 8 per cent. and in Belfast children much higher.

Comparison with the few previous surveys which can be regarded as at all comparable affords no evidence of any war-time increase in radiological rickets.

\section{II.-Correlation between radiological rickets and type of feeding, etc.}

From the histories obtained with regard to the 5071 children between 3 and 18 months of age table 3 has been compiled to compare the frequency of breast feeeding, administration of vitamin D preparations and exposure to radiation, amongst those with and without radiological signs of rickets. The centres have been grouped into five regions, London County, Northern England (including Liverpool), Midland and South (comprising the rest of England and Wales), Scotland and Ireland. The five age periods are shown separately and then combined. The definition of radiological rickets corresponds with ' active and healed' in table 1 .

Type of feeding has been distinguished by the six groups:-(1) Breast-fed only, up to the time of examination; (2) Breast feeding supplemented or followed by mixed solids without mention of bottle feeding; (3) Breast and bottle feeding, whether in sequence or conjunction; (4) Breast and bottle feeding, supplemented or followed by mixed solids; (5) Bottle-fed only, from birth to time of examination; (6) Bottle feeding supplemented or followed by mixed solids. Comparing the percentage who had ever been breast fed amongst 106 children radiologically positive with that for the 4965 negative at all ages, these are:-

Radiologically positive $68 \cdot 9 \pm 4 \cdot 5$

Radiologically negative $81 \cdot 5 \pm 0 \cdot 6$

A significantly lower proportion had, therefore, been breast fed at some time amongst the affected children. The contrast is seen better if we compare the percentages of children aged 3 to 9 months of age who had been breast fed only, viz.:-

Radiologically positive $4 \cdot 3 \pm 2 \cdot 4$

Radiologically negative $18 \cdot 7 \pm 0 \cdot 8$

There were only 3 children in the positive group at this age who had been entirely breast fed, two in Bristol and one in Ireland, for whom the diagnosis of the x-ray films was in some doubt.

The average duration of breast feeding, in months, is compared below for the radiologically positive and negative children who had ever been breast fed, distinguishing four age-groups. The numbers from which the mean durations are derived are the aggregates of the breast groups in the appropriate columns of table 3 .

\begin{tabular}{|c|c|c|c|c|c|c|c|c|}
\hline & \multicolumn{2}{|c|}{ 3-6 months } & \multicolumn{2}{|c|}{ 6-9 months } & \multicolumn{2}{|c|}{$9-12$ months } & \multicolumn{2}{|c|}{ 12-18 months } \\
\hline & $\mathbf{R}+$ & $\mathbf{R}-$ & $\mathbf{R}+$ & $\mathbf{R}-$ & $\mathbf{R}+$ & $\mathbf{R}-$ & $\mathbf{R}+$ & $\mathbf{R}-$ \\
\hline $\begin{array}{l}\text { London County } \\
\text { Midland and South } \\
\text { Northern England } \\
\text { Scottish towns }\end{array}$ & $\begin{array}{l}\overline{3 \cdot 3} \\
2 \cdot 6 \\
1 \cdot 8\end{array}$ & $\begin{array}{l}3 \cdot 2 \\
2 \cdot 9 \\
3 \cdot 0 \\
2 \cdot 9\end{array}$ & $\begin{array}{l}2 \cdot 0 \\
3 \cdot 3 \\
3 \cdot 0 \\
1 \cdot 8 \\
\end{array}$ & $\begin{array}{l}4 \cdot 4 \\
4 \cdot 3 \\
4 \cdot 4 \\
4 \cdot 0\end{array}$ & $\begin{array}{l}2 \cdot 3 \\
1 \cdot 3 \\
6 \cdot 6 \\
2 \cdot 5\end{array}$ & $\begin{array}{l}5 \cdot 7 \\
5 \cdot 3 \\
5 \cdot 3 \\
4 \cdot 5 \\
\end{array}$ & $\begin{array}{c}(2 \cdot 3) \\
- \\
(7 \cdot 0)\end{array}$ & $\begin{array}{l}5 \cdot 9 \\
5 \cdot 3 \\
6 \cdot 0 \\
4 \cdot 8\end{array}$ \\
\hline Great Britain $\quad \ldots$ & $2 \cdot 6$ & 3.0 & $2 \cdot 6$ & $4 \cdot 2$ & $3 \cdot 2$ & $5 \cdot 2$ & $(5 \cdot 8)$ & $5 \cdot 5$ \\
\hline Belfast and Dublin & $2 \cdot 2$ & $2 \cdot 3$ & $2 \cdot 7$ & $4 \cdot 6$ & 0 & $3 \cdot 4$ & $4 \cdot 7$ & $6 \cdot 2$ \\
\hline
\end{tabular}


TABLE 1

RADIOLOGICAL DIAGNOSIS OF RICKETS-FREQUENCY AMONGST CHILDREN EXAMINED IN EACH CENTRE AT AGES 3-18 MONTHS

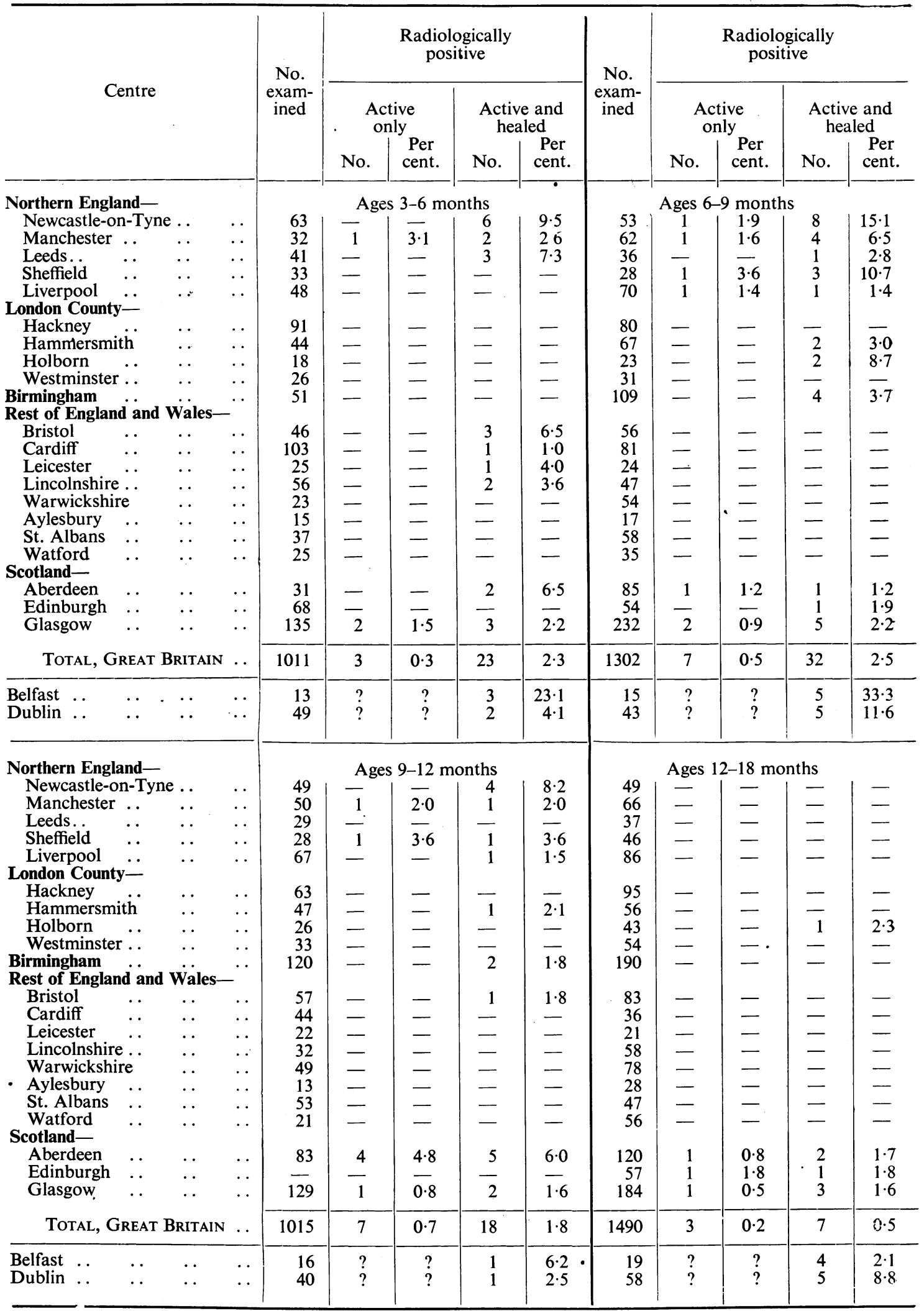


TABLE 2

RADIOLOGICAL DIAGNOSIS OF RICKETS-FREQUENCY IN GEOGRAPHICAL GROUPS OF AREAS

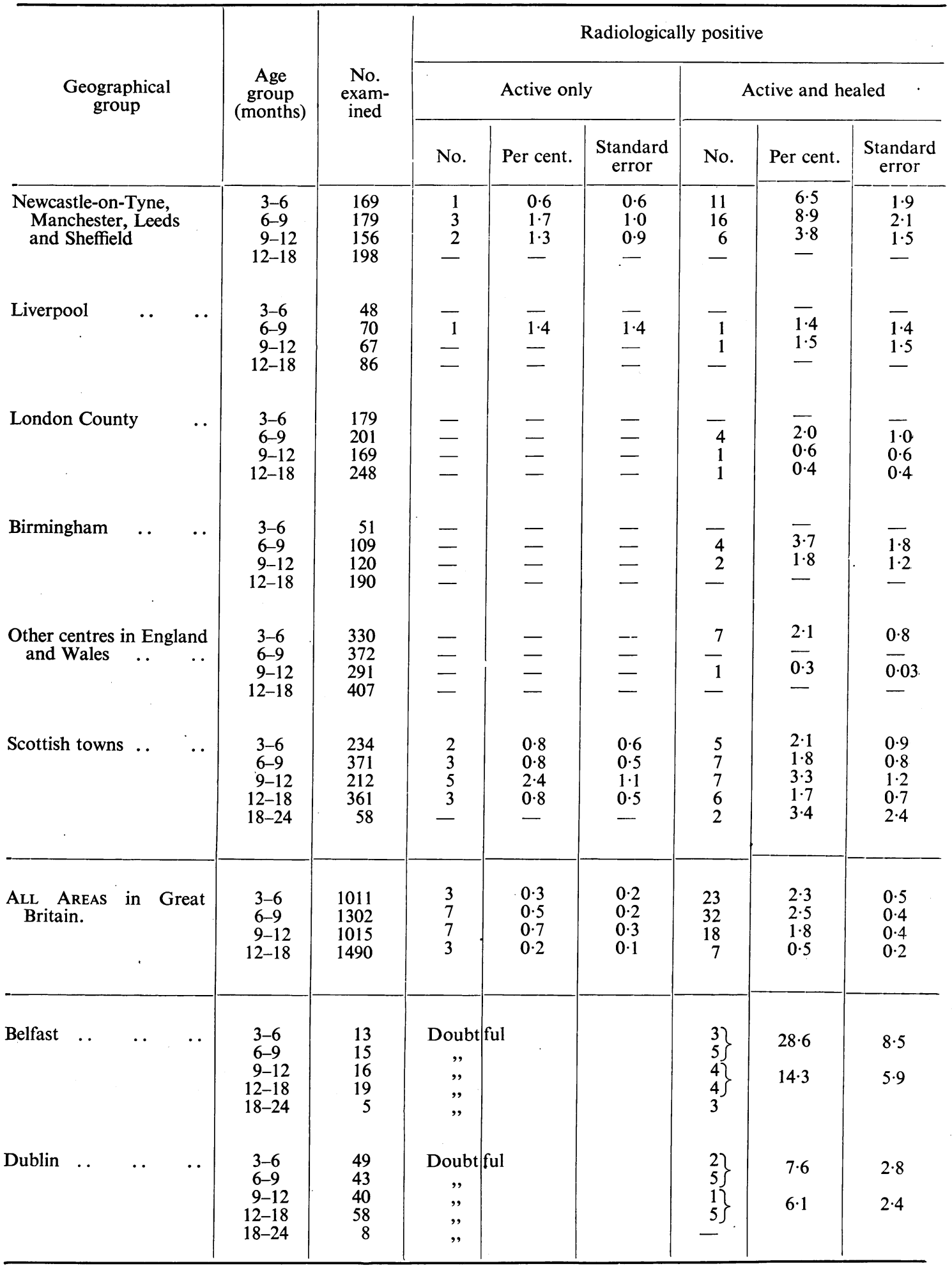


TABLE 3

\section{NUMBERS AND PROPORTIONS OF RADIOLOGICALLY POSITIVE AND NEGATIVE CHILDREN WHO HAD BEEN BREAST-FED, ETC.}

NoTES.-(1) Followed or supplemented by mixed solid diet.

(2) Per cent. of total who had ever been breast-fed (i.e. ratio of aggregate of first 4 lines to total).

\begin{tabular}{|c|c|c|c|c|c|c|c|c|c|c|c|c|}
\hline & \multicolumn{2}{|c|}{$\begin{array}{l}\text { London } \\
\text { County }\end{array}$} & \multicolumn{2}{|c|}{$\begin{array}{l}\text { Midland } \\
\text { and South }\end{array}$} & \multicolumn{2}{|c|}{$\begin{array}{l}\text { Northern } \\
\text { England }\end{array}$} & \multicolumn{2}{|c|}{ Scotland } & \multicolumn{2}{|c|}{ Ireland } & \multicolumn{2}{|c|}{ All areas } \\
\hline & $\mathbf{R}+$ & $\mathbf{R}-$ & $\mathbf{R}+$ & $\mathbf{R}-$ & $\mathbf{R}+$ & $\mathrm{R}-$ & $\mathbf{R}+$ & $\mathbf{R}-$ & $\mathbf{R}+$ & $\mathbf{R}-$ & $\mathbf{R}+$ & $\mathbf{R}-$ \\
\hline $\begin{array}{l}\text { Iges 3-6 months- } \\
\text { Breast-fed only } \\
\text { Breast-fed and M.S. (1) } \\
\text { Breast and bottle } \\
\text { Breast, bottle and M.S.(1) } \\
\text { Bottle fed only ... } \\
\text { Bottle-fed and M.S. (1).. }\end{array}$ & $\begin{array}{l}\bar{z} \\
\bar{z} \\
\overline{-}\end{array}$ & $\begin{array}{r}58 \\
4 \\
92 \\
6 \\
17 \\
2\end{array}$ & $\frac{\frac{2}{2}}{\frac{3}{-}}$ & $\begin{array}{r}106 \\
3 \\
189 \\
6 \\
66 \\
4\end{array}$ & $\begin{array}{r}\overline{2} \\
\overline{7} \\
2 \\
-\end{array}$ & $\begin{array}{r}55 \\
3 \\
105 \\
4 \\
38 \\
1\end{array}$ & $\begin{array}{c}-\overline{4} \\
\frac{1}{1}\end{array}$ & $\begin{array}{r}86 \\
4 \\
111 \\
25 \\
25 \\
1\end{array}$ & $\begin{array}{l}\overline{5} \\
\overline{-} \\
\bar{z}\end{array}$ & $\begin{array}{l}\frac{10}{36} \\
1 \\
10 \\
-\end{array}$ & $\begin{array}{r}2 \\
2 \\
18 \\
6 \\
-\end{array}$ & $\begin{array}{r}315 \\
14 \\
533 \\
19 \\
156 \\
8\end{array}$ \\
\hline $\begin{array}{l}\text { Total } \ldots \\
\begin{array}{l}\text { Per cent. breast-fed (2) } \\
\text { " } \quad \text { breast-fed only }\end{array} \\
. .\end{array}$ & $=$ & $\begin{array}{r}179 \\
. \quad 89 \\
32\end{array}$ & $\begin{array}{r}7 \\
57\end{array}$ & $\begin{array}{r}374 \\
81 \\
28\end{array}$ & $\begin{array}{l}11 \\
82 \\
- \\
\end{array}$ & $\begin{array}{r}206 \\
81 \\
27\end{array}$ & $\begin{array}{r}5 \\
80 \\
- \\
\end{array}$ & $\begin{array}{r}229 \\
89 \\
38\end{array}$ & $\begin{array}{r}5 \\
100 \\
- \\
\end{array}$ & $\begin{array}{l}57 \\
82 \\
18\end{array}$ & $\begin{array}{r}28 \\
79 \\
7 \\
\end{array}$ & $\begin{array}{r}1045 \\
84 \\
30\end{array}$ \\
\hline $\begin{array}{cc}\text { od-liver oil or Vit. D } & . \\
\text { unshine (natural only) } & \ldots \\
, \quad \quad(\text { artificial) } & \ldots \\
\end{array}$ & $\overline{-}$ & $\begin{array}{r}162 \\
25 \\
2 \\
\end{array}$ & $\begin{array}{r}4 \\
6 \\
- \\
\end{array}$ & $\begin{array}{r}281 \\
283 \\
3 \\
\end{array}$ & $\begin{array}{r}11 \\
8 \\
- \\
\end{array}$ & $\begin{array}{r}164 \\
103 \\
- \\
\end{array}$ & $\begin{array}{r}5 \\
4 \\
- \\
\end{array}$ & $\begin{array}{r}197 \\
116 \\
- \\
\end{array}$ & $\frac{2}{-}$ & $\frac{23}{1}$ & $\begin{array}{l}22 \\
18 \\
- \\
\end{array}$ & $\begin{array}{r}827 \\
527 \\
6\end{array}$ \\
\hline $\begin{array}{l}\text { Ages 6-9 months- } \\
\text { Breast-fed only } \\
\text { Breast-fed and M.S. (1) } \\
\text { Breast and bottle } \\
\text { Breast, bottle and M.S.(1) } \\
\text { Bottle-fed only _... } \\
\text { Bottle-fed and M.S. (1).. }\end{array}$ & $\begin{array}{c}\overline{-} \\
1 \\
- \\
-\end{array}$ & $\begin{array}{r}12 \\
58 \\
23 \\
87 \\
5 \\
12\end{array}$ & $\begin{array}{c}\overline{-} \\
\overline{1} \\
\frac{1}{2}\end{array}$ & $\begin{array}{r}71 \\
69 \\
101 \\
151 \\
40 \\
45\end{array}$ & $\begin{array}{r}2 \\
1 \\
10 \\
2 \\
2\end{array}$ & $\begin{array}{l}81 \\
16 \\
21\end{array}$ & $\begin{array}{c}\overline{-} \\
1 \\
3 \\
1 \\
2\end{array}$ & $\begin{array}{r}20 \\
73 \\
38 \\
152 \\
20 \\
61\end{array}$ & $\begin{array}{c}\frac{1}{6} \\
1 \\
1 \\
1\end{array}$ & $\begin{array}{r}6 \\
3 \\
13 \\
9 \\
7 \\
10\end{array}$ & $\begin{array}{r}1 \\
2 \\
10 \\
17 \\
5 \\
7\end{array}$ & $\begin{array}{r}126 \\
255 \\
220 \\
480 \\
88 \\
149\end{array}$ \\
\hline 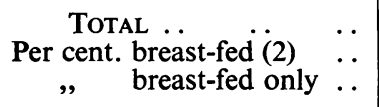 & $\begin{array}{c}4 \\
(100) \\
-\end{array}$ & $\begin{array}{r}197 \\
91 \\
6\end{array}$ & $\begin{array}{r}4 \\
25 \\
-\end{array}$ & $\begin{array}{r}82 \\
15\end{array}$ & $\begin{array}{l}17 \\
76 \\
-\end{array}$ & $\begin{array}{r}232 \\
84 \\
7\end{array}$ & $\begin{array}{r}7 \\
57 \\
-\end{array}$ & $\begin{array}{r}364 \\
78 \\
6\end{array}$ & $\begin{array}{l}80 \\
10\end{array}$ & $\begin{array}{l}03 \\
12\end{array}$ & $\begin{array}{r}42 \\
71 \\
2\end{array}$ & $\begin{array}{r}1318 \\
82 \\
10\end{array}$ \\
\hline $\begin{array}{cc}\text { Cod-liver oil or Vit. D } & \ldots \\
\text { Sunshine (natural only) } & \ldots \\
, \quad \quad \text { (artificial) } & \ldots\end{array}$ & $\underline{-}$ & $\begin{array}{r}187 \\
33 \\
3\end{array}$ & $\frac{3}{-}$ & $\begin{array}{r}401 \\
370 \\
9\end{array}$ & $\begin{array}{l}14 \\
12 \\
-\end{array}$ & $\begin{array}{r}193 \\
137 \\
4\end{array}$ & $\begin{array}{r}7 \\
5 \\
-\end{array}$ & $\begin{array}{r}319 \\
230 \\
3\end{array}$ & 1 & $\begin{array}{r}25 \\
1 \\
1\end{array}$ & $\begin{array}{l}32 \\
18 \\
-\end{array}$ & $\begin{array}{r}1125 \\
771 \\
20\end{array}$ \\
\hline $\begin{array}{l}\text { Ages 9-12 months- } \\
\text { Breast-fed only } \\
\text { Breast-fed and M.S. (1) } \\
\text { Breast and bottle } \\
\text { Breast, bottle and M.S.(1) } \\
\text { Bottle-fed only ... .. } \\
\text { Bottle-fed and M.S. (1).. }\end{array}$ & $\begin{array}{l}\bar{z} \\
\overline{1} \\
\overline{-}\end{array}$ & $\begin{array}{r}7 \\
55 \\
79 \\
3 \\
24\end{array}$ & $\begin{array}{l}\bar{z} \\
\frac{3}{z}\end{array}$ & $\begin{array}{r}4 \\
134 \\
13 \\
184 \\
7 \\
66\end{array}$ & $\frac{\overline{1}}{\frac{2}{4}}$ & $\begin{array}{r}1 \\
69 \\
12 \\
93 \\
5 \\
36\end{array}$ & $\frac{\overline{1}}{\frac{7}{2}}$ & $\frac{\overline{39}}{\frac{\overline{114}}{52}}$ & $\begin{array}{l}\bar{z} \\
\frac{2}{2}\end{array}$ & $\begin{array}{r}3 \\
14 \\
6 \\
15 \\
2 \\
14\end{array}$ & $\begin{array}{r}\overline{2} \\
10 \\
2 \\
6\end{array}$ & $\begin{array}{r}15 \\
311 \\
31 \\
485 \\
17 \\
192\end{array}$ \\
\hline $\begin{array}{ll}\text { ToTAL .. } & \\
\text { Per cent. breast-fed (2) } & \ldots\end{array}$ & $\begin{array}{r}1 \\
(100)\end{array}$ & $\begin{array}{r}168 \\
84\end{array}$ & $\begin{array}{r}3 \\
100\end{array}$ & $\begin{array}{r}408 \\
82\end{array}$ & $\begin{array}{r}7 \\
43\end{array}$ & $\begin{array}{r}216 \\
81\end{array}$ & 71 & $\begin{array}{r}205 \\
75\end{array}$ & $\underline{2}$ & $\begin{array}{l}54 \\
70\end{array}$ & $\begin{array}{l}20 \\
60\end{array}$ & $\begin{array}{r}1051 \\
80\end{array}$ \\
\hline $\begin{array}{cc}\text { Cod-liver oil or Vit. D } & \ldots \\
\text { Sunshine (natural only) } & \ldots \\
\quad, \quad(\text { artificial) } & \ldots\end{array}$ & $\frac{1}{-}$ & $\begin{array}{r}158 \\
28 \\
1\end{array}$ & $\begin{array}{r}2 \\
1 \\
-\end{array}$ & $\begin{array}{r}360 \\
320 \\
17\end{array}$ & $\begin{array}{l}0 \\
5 \\
1\end{array}$ & $\begin{array}{r}184 \\
136 \\
4\end{array}$ & $\begin{array}{r}4 \\
5 \\
-\end{array}$ & $\begin{array}{r}181 \\
150 \\
1\end{array}$ & $\overline{-}$ & 2 & $\begin{array}{r}13 \\
11 \\
1\end{array}$ & $\begin{array}{r}920 \\
636 \\
23\end{array}$ \\
\hline $\begin{array}{l}\text { Ages } 12-15 \text { months- } \\
\text { Breast-fed and M.S. (1) } \\
\text { Breast and bottle } \\
\text { Breast, bottle and M.S. (1) } \\
\text { Breast-fed only _.. .. } \\
\text { Bottle-fed and M.S. (1).. }\end{array}$ & $\begin{array}{l}E \\
\bar{z} \\
-\end{array}$ & $\begin{array}{r}57 \\
1 \\
63 \\
19\end{array}$ & $\begin{array}{l}\bar{z} \\
\overline{-}\end{array}$ & $\begin{array}{r}120 \\
1 \\
157 \\
1 \\
54\end{array}$ & $\begin{array}{l}\bar{z} \\
\bar{z}\end{array}$ & $\begin{array}{r}48 \\
2 \\
76 \\
32\end{array}$ & $\frac{\frac{1}{2}}{1}$ & $\begin{array}{r}\frac{67}{125} \\
1 \\
49\end{array}$ & $\frac{\overline{2}}{\frac{2}{3}}$ & $\begin{array}{r}11 \\
3 \\
15 \\
1 \\
7\end{array}$ & $\frac{1}{4}$ & $\begin{array}{r}303 \\
7 \\
436 \\
3 \\
161\end{array}$ \\
\hline $\begin{array}{ll}\text { Total .. } & \ldots \\
\text { Per cent. breast-fed (2) } & \ldots\end{array}$ & - & $\begin{array}{r}140 \\
86\end{array}$ & $\overline{-}$ & $\begin{array}{r}333^{\circ} \\
84\end{array}$ & - & $\begin{array}{r}158 \\
80\end{array}$ & $\begin{array}{r}4 \\
75 \\
\end{array}$ & $\begin{array}{r}242 \\
79\end{array}$ & $\begin{array}{r}5 \\
40\end{array}$ & $\begin{array}{l}37 \\
81\end{array}$ & $\begin{array}{r}9 \\
56\end{array}$ & $\begin{array}{r}910 \\
82\end{array}$ \\
\hline $\begin{array}{cc}\text { Cod-liver oil or Vit. D } & \text {. } \\
\text { Sunshine (natural only) } & \ldots \\
\quad, \quad(\text { artificial) } & \ldots\end{array}$ & $\bar{z}$ & $\begin{array}{r}130 \\
31 \\
5\end{array}$ & $\bar{z}$ & $\begin{array}{r}315 \\
243 \\
16\end{array}$ & $\overline{-}$ & $\begin{array}{r}134 \\
91 \\
5\end{array}$ & $\begin{array}{r}3 \\
3 \\
-\end{array}$ & $\begin{array}{r}214 \\
139 \\
7\end{array}$ & $\begin{array}{r}2 \\
1 \\
-\end{array}$ & $\begin{array}{r}19 \\
1 \\
-\end{array}$ & $\begin{array}{r}5 \\
4 \\
-\end{array}$ & $\begin{array}{r}812 \\
505 \\
33\end{array}$ \\
\hline
\end{tabular}

ges 3-6 months-

Breast-fed and M.S. (1)

Breast, bottle and M.S.(1)

Bottle fed only 
TABLE 3-(continued)

\begin{tabular}{|c|c|c|c|c|c|c|c|c|c|c|c|c|}
\hline & \multicolumn{2}{|c|}{$\begin{array}{l}\text { London } \\
\text { County }\end{array}$} & \multicolumn{2}{|c|}{$\begin{array}{c}\text { Midland } \\
\text { and South }\end{array}$} & \multicolumn{2}{|c|}{$\begin{array}{l}\text { Northern } \\
\text { England }\end{array}$} & \multicolumn{2}{|c|}{ Scotland } & \multicolumn{2}{|c|}{ Ireland } & \multicolumn{2}{|c|}{ All areas } \\
\hline & $\mathbf{R}+$ & $\mathbf{R}-$ & $\mathbf{R}+$ & $\mathbf{R}-$ & $\mathbf{R}+$ & $\mathbf{R}-$ & $\mathbf{R}+$ & $\mathbf{R}-$ & $\mathbf{R}+$ & $\mathbf{R}-$ & $\mathbf{R}+$ & $\mathbf{R}-$ \\
\hline $\begin{array}{l}\text { Ages } 15-18 \text { months-- } \\
\text { Breast-fed and M.S. (1).. } \\
\text { Breast, bottle and M.S.(1) } \\
\text { Bottle-fed and M.S. (1).. }\end{array}$ & $\begin{array}{r}- \\
-\end{array}$ & $\begin{array}{l}35 \\
60 \\
12\end{array}$ & - & $\begin{array}{r}80 \\
120 \\
64 \\
\end{array}$ & - & $\begin{array}{l}40 \\
55 \\
31\end{array}$ & $\overline{2}$ & $\begin{array}{l}27 \\
57 \\
29\end{array}$ & $\begin{array}{l}\overline{3} \\
1\end{array}$ & $\begin{array}{r}8 \\
16 \\
7\end{array}$ & $\begin{array}{l}-4 \\
3 .\end{array}$ & $\begin{array}{l}190 \\
308 \\
143\end{array}$ \\
\hline $\begin{array}{ll}\text { ToTaL . . } & \ldots \\
\text { Per cent. breast-fed (2) } & \ldots\end{array}$ & 100 & $\begin{array}{r}107 \\
89\end{array}$ & - & $\begin{array}{r}264 \\
76\end{array}$ & - & $\begin{array}{r}126 \\
75\end{array}$ & $\underline{2}$ & $\begin{array}{r}113 \\
74\end{array}$ & $\begin{array}{r}4 \\
75\end{array}$ & $\begin{array}{l}31 \\
77\end{array}$ & $\begin{array}{r}7 \\
67\end{array}$ & $\begin{array}{r}641 \\
78\end{array}$ \\
\hline $\begin{array}{cc}\text { Cod-liver oil or Vit. D } & \ldots \\
\text { Sunshine (natural only) } & \ldots \\
,, \quad \text { (artificial) } & \ldots\end{array}$ & $\frac{1}{-}$ & $\begin{array}{r}101 \\
7 \\
8\end{array}$ & - & $\begin{array}{r}235 \\
200 \\
17\end{array}$ & - & $\begin{array}{r}102 \\
64 \\
8\end{array}$ & $\begin{array}{r}1 \\
1 \\
-\end{array}$ & $\begin{array}{r}101 \\
85 \\
11\end{array}$ & $\frac{2}{-}$ & $\begin{array}{r}21 \\
1 \\
6 \\
\end{array}$ & $\begin{array}{r}5 \\
2 \\
-\end{array}$ & $\begin{array}{r}560 \\
357 \\
50 \\
\end{array}$ \\
\hline $\begin{array}{l}\text { All ages 3-18 months- } \\
\text { Breast-fed only } . \dot{ } \\
\text { Breast-fed and M.S. (1).. } \\
\text { Breast and bottle } \\
\text { Breast, bottle and M.S. (1) } \\
\text { Bottle fed only } \\
\text { Bottle-fed and M.S. (1).. }\end{array}$ & $\begin{array}{l}- \\
-1 \\
5 \\
-\end{array}$ & $\begin{array}{r}777 \\
209 \\
116 \\
295 \\
25 \\
69\end{array}$ & $\begin{array}{c}2 \\
3 \\
3 \\
4 \\
2\end{array}$ & $\begin{array}{l}181 \\
406 \\
304 \\
618 \\
114 \\
233\end{array}$ & $\begin{array}{r}-5 \\
8 \\
12 \\
4 \\
6\end{array}$ & $\begin{array}{r}73 \\
212 \\
164 \\
309 \\
59 \\
121\end{array}$ & $\begin{array}{l}-2 \\
5 \\
9 \\
2 \\
7\end{array}$ & $\begin{array}{r}106 \\
210 \\
149 \\
450 \\
46 \\
192\end{array}$ & $\begin{array}{r}1 \\
11 \\
6 \\
3 \\
5\end{array}$ & $\begin{array}{l}19 \\
36 \\
58 \\
56 \\
20 \\
38\end{array}$ & $\begin{array}{r}3 \\
7 \\
28 \\
35 \\
13 \\
20\end{array}$ & $\begin{array}{r}456 \\
1073 \\
791 \\
1728 \\
264 \\
653\end{array}$ \\
\hline $\begin{array}{ll}\quad \text { TotaL .. } & \ldots \\
\text { Per cent. breast-fed (2) } & \ldots \\
\text { Per cent. breast-fed only } & \ldots\end{array}$ & $\begin{array}{r}6 \\
100 \\
-\end{array}$ & $\begin{array}{r}791 \\
88 \\
10\end{array}$ & $\begin{array}{l}14 \\
57 \\
14\end{array}$ & $\begin{array}{r}1856 \\
81 \\
10\end{array}$ & $\begin{array}{l}35 \\
71 \\
-\end{array}$ & $\begin{array}{r}938 \\
81 \\
8\end{array}$ & $\begin{array}{l}25 \\
67 \\
-\end{array}$ & $\begin{array}{r}1153 \\
79 \\
9\end{array}$ & $\begin{array}{r}26 \\
69 \\
4\end{array}$ & $\begin{array}{r}227 \\
75 \\
8\end{array}$ & $\begin{array}{r}106 \\
68 \cdot 9 \\
2 \cdot 8\end{array}$ & $\begin{array}{r}4965 \\
81 \cdot 5 \\
9 \cdot 2\end{array}$ \\
\hline $\begin{array}{cc}\text { Cod-liver oil or Vit. D } & \ldots \\
\text { Sunshine (natural only) } & \ldots \\
,, \quad \text { (artificial) } & \ldots\end{array}$ & $\frac{4}{-}$ & $\begin{array}{r}738 \\
124 \\
19\end{array}$ & $\begin{array}{r}9 \\
7 \\
-\end{array}$ & $\begin{array}{r}1592 \\
1416 \\
62\end{array}$ & $\begin{array}{r}31 \\
25 \\
1\end{array}$ & $\begin{array}{r}777 \\
531 \\
21\end{array}$ & $\begin{array}{l}20 \\
18 \\
-\end{array}$ & $\begin{array}{r}1012 \\
720 \\
22\end{array}$ & $\begin{array}{r}12 \\
2 \\
-\end{array}$ & $\begin{array}{r}125 \\
5 \\
8\end{array}$ & $\begin{array}{r}77 \\
53 \\
1\end{array}$ & $\begin{array}{r}4244 \\
2796 \\
132\end{array}$ \\
\hline
\end{tabular}

At ages 6-9 months the radiologically positive children recorded 1.6 months less breast feeding on the average than the negative children in Great Britain and about 2 months less in the Irish towns. At 9-12 months the deficits were 2 and $3 \frac{1}{2}$ months respectively. At 12-18 months there were only 4 positive children ever breast fed in Great Britain and no reliance can be placed on the comparison.

When the children never breast fed are included counting their duration as zero, the comparison again reveals a deficit of about 2 months for the radiologically positive children aged 6-12 months, as shown below.

\begin{tabular}{|c|c|c|c|c|c|c|c|c|}
\hline & \multicolumn{2}{|c|}{ 3-6 months } & \multicolumn{2}{|c|}{ 6-9 months } & \multicolumn{2}{|c|}{$9-12$ months } & \multicolumn{2}{|c|}{$12-18$ months } \\
\hline & $\mathbf{R}+$ & $\mathbf{R}-$ & $\mathrm{R}+$ & $\mathbf{R}-{ }^{\circ}$ & $\mathbf{R}+$ & $\mathrm{R}-$ & $\mathbf{R}+$ & $\mathbf{R}-$ \\
\hline $\begin{array}{l}\text { London County } \\
\text { Midland and South } \\
\text { Northern England } \\
\text { Scottish towns }\end{array}$ & $\begin{array}{l}-\overline{1 \cdot 9} \\
2 \cdot 2 \\
1 \cdot 5\end{array}$ & $\begin{array}{l}2 \cdot 9 \\
2 \cdot 3 \\
2 \cdot 5 \\
2 \cdot 6\end{array}$ & $\begin{array}{l}2: 0 \\
0 \cdot 8 \\
2 \cdot 2 \\
1 \cdot 1\end{array}$ & $\begin{array}{l}4 \cdot 0 \\
3 \cdot 5 \\
3 \cdot 7 \\
3 \cdot 1\end{array}$ & $\begin{array}{l}2 \cdot 3 \\
1 \cdot 3 \\
2 \cdot 8 \\
1 \cdot 8\end{array}$ & $\begin{array}{l}4 \cdot 8 \\
4 \cdot 4 \\
4 \cdot 4 \\
3 \cdot 3\end{array}$ & $\begin{array}{l}(2 \cdot 3) \\
- \\
(3 \cdot 5)\end{array}$ & $\begin{array}{l}5 \cdot 3 \\
4 \cdot 3 \\
4 \cdot 7 \\
3 \cdot 7\end{array}$ \\
\hline Great Britain $\quad$. & $1 \cdot 9$ & $2 \cdot 5$ & $1 \cdot 8$ & $3 \cdot 5$ & $2 \cdot 2$ & $4 \cdot 2$ & $(3 \cdot 3)$ & $4 \cdot 4$ \\
\hline Belfast and Dublin & $2 \cdot 2$ & $1 \cdot 9$ & $2 \cdot 2$ & $3 \cdot 0$ & 0 & $2 \cdot 4$ & $2 \cdot 6$ & $4 \cdot 8$ \\
\hline
\end{tabular}

Comparison of the percentages of all the children examined at ages 6-9 months who had been breastfed only, and who had ever been breast fed, in the 5 regions gives the following:-

Midland and South $\quad \therefore \quad$.. $14.8 \pm 1.6$

Northern England . . . . $\quad 6.8 \pm 1.6$

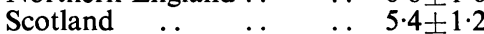

Ireland $\quad . \quad \ldots \quad \ldots \quad \ldots 12 \cdot 1 \pm 4 \cdot 3$

Ever breast-fed

$91 \cdot 5 \pm 2 \cdot 0$

$82 \cdot 2 \pm 1 \cdot 8$

$83 \cdot 5+2 \cdot 4$

$72 \cdot 0 \pm 2 \cdot 3$

$67 \cdot 2 \pm 6 \cdot 2$

The percentages who had ever been breast-fed were significantly better in England than in Scotland or Ireland, and also better in London than elsewhere, and table 3 shows that this was true also at 9-12 months. The superiority of the London proportion over other areas was evident also at the later ages 12-18 months. The proportion breast-fed only up to the time of examination at 6-9 months was significantly higher in the towns of the Midlands and South than in either London or the North.

Cod-liver oil or some other vitamin D preparation had been taken by 77 out of 106 children who were radiologically positive $(72 \cdot 7 \pm 5 \cdot 0$ per cent.), and by 
4240 out of 4965 who were radiologically negative $(85.5 \pm 0.5$ per cent.), the proportion being significantly smaller in the positive group. The contrast was greater for children aged 9-18 months (64 and 88 per cent.) than for children aged 3-9 months (77 and 83 per cent.). Since some of the children had presumably been treated in the past for the rickets now observed in a healed state, it cannot be assumed, of course, that in the 77 children with history of rickets the cod-liver oil preparations had been given prior to its development. Details of the age from which such preparations were given, and of the dosage, are available on the records, but have not been subjected to any statistical analysis.

The enquiry as to exposure of the children to natural or artificial radiation elicited the information that for 50 per cent. of the radiologically positive group, compared with 56 per cent. of the negative group, some effort had been made to give the child access to natural sunshine, the difference not being statistically significant. The proportion of all children for whom this question was answered affirmatively was highest in the Midland and Southern towns (76 per cent.), and lowest in London County (16 per cent.) and in the Irish towns ( 3 per cent.). Artificial radiation had been used for only 1 of the 106 children with radiological signs of rickets and for 2.6 per cent. of those without signs.

\section{Summary of Section II}

Amongst 106 children aged 3-18 months with radiological signs of rickets 69 per cent. had been breast-fed at some time compared with $81 \frac{1}{2}$ per cent. of 4965 children of the same ages without such signs, this difference being statistically significant.* Amongst 70 radiologically positive children aged 3-9 months only 3, two of rather doubtful diagnosis, had been breast-fed only, compared with 19 per cent. . of the control group. For children aged 9-12 months in Great Britain who had been breast-fed at some time the mean duration of such feeding was 3.2 months for those who showed radiological signs compared with 5.2 months for those who did not; and at 6-9 months of age the deficit amounted to 1.6 months. When those who had never been breast-fed were included, the average duration of breast feeding for all positive children aged 9-12 months was $2 \cdot 2$ months, compared with $4 \cdot 2$ for the controls; and at 6-9 months of age the deficit was 1.7 months.

All children aged 6-9 months showed a higher proportion with record of breast feeding in England than in Scotland or Ireland, and in London than elsewhere.

Cod-liver oil or other vitamin D preparation had been given to 73 per cent. of radiologically positive children, compared with $85 \frac{1}{2}$ per cent. of the radiologically negative, a significant deficiency. No

\footnotetext{
* Throughout this report the conventional criterion of what constitutes 'significance' has been used, namely, that a difference between the two averages (or percentages) as great as the one observed would not occur by 'chance' oftener than once in 22 trials, if the samples being compared were taken at random out of the same population. In other words, the odds are at least 21 to 1 against such a difference being explicable by variations arising merely from the smallness of the samples: and consequently some other explanation of the difference should be looked for.
}

appreciable difference was found between the proportions said to have been exposed to natural or artificial radiation.

\section{III.-Clinical diagnosis of rickets}

The question was asked 'Is rickets present or not? (This refers to active rickets at the present time) '; and also the further question 'Has rickets ever been present?' The answers 'Yes' or 'No' to the first question were based on clinical signs and were made without knowledge of the $\mathrm{x}$-ray findings. Since it is important to ascertain what correspondence there is between the presence of radiological signs of rickets, and the presence or absence of the clinical signs which in the past have been regarded as diagnostic of the disease, table 4 has been compiled in similar form to table 1 to show (1) the percentages of children examined at each centre who were said to exhibit clinical signs of active rickets, (2) the numbers of these who were classed as radiologically positive (active or healed) and negative respectively, and (3) the numbers of the clinically negative children who were classed as radiologically positive and negative respectively. The totals examined are given in table 1 and are not repeated, being the sum of the four sub-groups as defined above. Amongst the 4818 children examined in Great Britain at ages 3-18 months 604 were said to have clinical evidence of active rickets, and in addition 144 were said to have had rickets previously (these not being included in the table). The proportion with clinical active rickets varied little with age, as shown below by the percentages of the total examined:-

\begin{tabular}{|c|c|c|c|c|}
\hline \multirow{6}{*}{$\begin{array}{l}\text { Ages: } \\
\text { 3-6 months } \\
\text { 6-9 months } \\
9-12 \text { months } \\
12-18 \text { months }\end{array}$} & \multicolumn{2}{|c|}{ Clinical Rickets } & \multicolumn{2}{|c|}{ Radiological Rickets } \\
\hline & Active & Past. & Active & Healed \\
\hline & $11 \cdot 8$ & 0.6 & $0 \cdot 3$ & $2 \cdot 0$ \\
\hline & $12 \cdot 1$ & $1 \cdot 6$ & 0.5 & $2 \cdot 0$ \\
\hline & $11 \cdot 1$ & $3 \cdot 0$ & 0.7 & $1 \cdot 1$ \\
\hline & $13 \cdot 8$ & $5 \cdot 8$ & $0 \cdot 2$ & $0 \cdot 3$ \\
\hline All ages $3-18 \mathrm{~m}$ & hs $12 \cdot 5$ & $3 \cdot 0$ & 0.4 & $1 \cdot 3$ \\
\hline
\end{tabular}

The proportion diagnosed on clinical grounds as having active rickets was $12 \frac{1}{2}$ per cent., compared with less than one-half per cent. so diagnosed radiologically; and the proportion ascertained clinically as having developed rickets up to 6 months of age was about 13 per cent. compared with 2.4 per cent. on radiological evidence.

The percentage rates of clinical active rickets in table 4 range from nil in St. Albans and Watford to 61 per cent. at all ages in Sheffield. For the regional groups of towns as used in table 2, these rates were as follows:-

\begin{tabular}{|c|c|c|c|c|c|}
\hline $\begin{array}{l}\text { Newcastle, } \\
\text { chester, Leed }\end{array}$ & $\begin{array}{l}\text { Man- } \\
\text { and }\end{array}$ & $\begin{array}{l}\text { 3-6 } \\
\text { months }\end{array}$ & $\begin{array}{c}\text { 6-9 } \\
\text { months }\end{array}$ & $\begin{array}{c}\text { 9-12 } \\
\text { months }\end{array}$ & $\begin{array}{l}12-18 \\
\text { months }\end{array}$ \\
\hline Sheffield .. & . & $23 \cdot 7$ & $13 \cdot 4$ & $13 \cdot 5$ & $20 \cdot 2$ \\
\hline Liverpool & 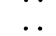 & $6 \cdot 2$ & $21 \cdot 4$ & $26 \cdot 9$ & $30 \cdot 2$ \\
\hline London County & $\cdots$ & $2 \cdot \overline{8}$ & $3 \cdot 0$ & $4 \cdot 1$ & $6 \cdot 9$ \\
\hline Birmingham & & $13 \cdot 7$ & 9 . & 5 . & 2 . \\
\hline \multicolumn{6}{|c|}{ Rest of England and } \\
\hline Wales & & $10 \cdot 9$ & $8 \cdot 9$ & $9 \cdot 6$ & $5 \cdot 2$ \\
\hline Scottish Towns & & $12 \cdot 0$ & $18 \cdot 7$ & $18 \cdot 8$ & $27 \cdot 1$ \\
\hline Belfast & . & $61 \cdot 5$ & 60.0 & $43 \cdot 7$ & $57 \cdot 9$ \\
\hline Dublin & & $34 \cdot 7$ & $27 \cdot 9$ & $12 \cdot 5$ & $19 \cdot 0$ \\
\hline
\end{tabular}


For Liverpool, London and the Scottish towns the rate increases with advancing age, whereas in Birmingham and other parts of the Midlands and South it decreases. Except in the case of Liverpool after 6 months of age, the order of ranking of these regions is similar to that for radiological rickets, but on other grounds correspondence between the two definitions is very poor, as shown below.

The correlation between a diagnosis of clinical active rickets and the presence of radiological signs of active, healing or healed rickets in the 4818 children aged 3-18 months examined in Great Britain is indicated by grouping the totals from table 4 as follows:-

\begin{tabular}{|c|c|c|c|c|c|}
\hline \multirow{3}{*}{$\begin{array}{l}\text { Clinical } \\
\text { Active } \\
\text { Rickets }\end{array}$} & \multicolumn{3}{|c|}{$\begin{array}{l}\text { Radiological } \\
\text { tive Negative }\end{array}$} & \multirow[b]{2}{*}{ Total } & \multirow{2}{*}{$\begin{array}{l}\text { Per cent } \\
\text { positive }\end{array}$} \\
\hline & & Sitive & $\begin{array}{l}\text { Negative } \\
577\end{array}$ & & \\
\hline & $\begin{array}{l}\text { Present } \\
\text { Absent }\end{array}$ & $\begin{array}{l}32 \\
48\end{array}$ & $\begin{array}{r}572 \\
4166\end{array}$ & $\begin{array}{r}604 \\
4214\end{array}$ & $\begin{array}{l}5 \cdot 3 \pm 0 \\
1 \cdot 2 \pm 0\end{array}$ \\
\hline Tot & . & 80 & 4738 & 4818 & \\
\hline
\end{tabular}

Out of 604 children diagnosed clinically as having active rickets only 32 (5.3 per cent.) showed radiological signs, 9 said to be active and 23 healed. On the other hand amongst 4214 not clinically diagnosed as having active rickets there were 48 (1.2 per cent.) who showed radiological signs, 11 said to be active and 37 healed. In Bristol 159 children were examined at ages 3-12 months; 60 of them were said to have clinical rickets, but of these
60 only 1 showed radiological signs compared with 3 amongst the 99 without clinical rickets. In Aberdeen 199 were examined at these ages, 63 being clinically positive, of whom 4 showed radiological signs compared with 4 amongst the 136 clinically negative children. It would appear from this that there is very little relation between the results of the two methods of diagnosis in Great Britain. The clinical method failed to identify half the children diagnosed radiologically as active rickets, notwithstanding that the clinical net was spread so much wider than the radiological.

Belfast and Dublin children showed a more consistent relationship since out of $\mathbf{8 0}$ diagnosed as clinical active rickets 24 showed radiological signs (30 per cent.) whilst out of 173 not clinically diagnosed as having active rickets two showed radiological signs (1.2 per cent., as for Great Britain).

The frequencies of the four clinical signs. (1) delayed closure of the anterior fontanelle, (2) craniotabes, (3) enlarged epiphyses at the wrists, and (4) enlarged costo-chondral junctions are compared below for the clinically positive and negative groups at certain ages. In calculating the proportions of children exhibiting these signs doubtful cases were excluded both from numerator and denominator. The clinically rachitic children are denoted by $\mathrm{C}+$ and those not so diagnosed by $\mathrm{C}-$. Percentages based on less than 20 children are shown in parenthesis.

\begin{tabular}{|c|c|c|c|c|c|c|c|c|}
\hline \multirow{3}{*}{ Age (months) } & \multicolumn{8}{|c|}{ Percentages exhibiting the clinical sign specified } \\
\hline & \multicolumn{2}{|c|}{ North of England } & \multicolumn{2}{|c|}{ Scottish towns } & \multicolumn{2}{|c|}{ London county } & \multicolumn{2}{|c|}{ Rest of Great Britain } \\
\hline & $\mathrm{C}+$ & $\mathrm{C}-$ & $\mathrm{C}+$ & $\mathrm{C}-$ & $\mathrm{C}+$ & $\mathrm{C}-$ & $\mathrm{C}+$ & $\mathrm{C}-$ \\
\hline & \multicolumn{8}{|c|}{ Anterior fontanelle open } \\
\hline \multirow[t]{2}{*}{$\begin{array}{c}3-9 \\
9-12 \\
12-15 \\
15-18\end{array}$} & $\begin{array}{r}100 \\
97 \\
94 \\
79\end{array}$ & $\begin{array}{l}98 \\
91 \\
71 \\
50\end{array}$ & $\begin{array}{r}100 \\
100 \\
89 \\
75\end{array}$ & $\begin{array}{l}98 \\
90 \\
78 \\
46\end{array}$ & $\begin{array}{r}(100) \\
(100) \\
(60) \\
(29)\end{array}$ & $\begin{array}{l}98 \\
84 \\
63 \\
38\end{array}$ & $\begin{array}{r}100 \\
94 \\
(89) \\
(57)\end{array}$ & $\begin{array}{l}97 \\
77 \\
56 \\
36\end{array}$ \\
\hline & \multicolumn{8}{|c|}{ Craniotabes } \\
\hline \multirow[t]{2}{*}{$\begin{array}{c}3-6 \\
6-9 \\
9-12 \\
12-18\end{array}$} & $\begin{array}{r}59 \\
6 \\
3 \\
2\end{array}$ & $\begin{array}{l}1 \\
0 \\
0 \\
0\end{array}$ & $\begin{array}{l}50 \\
30 \\
14 \\
14\end{array}$ & $\begin{array}{l}0 \\
2 \\
0 \\
1\end{array}$ & $\begin{array}{c}(0) \\
(20) \\
(0) \\
(0)\end{array}$ & $\begin{array}{l}6 \\
1 \\
1 \\
0\end{array}$ & $\begin{array}{r}65 \\
25 \\
6 \\
0\end{array}$ & $\begin{array}{l}3 \\
1 \\
0 \\
0\end{array}$ \\
\hline & \multicolumn{8}{|c|}{ Enlarged epiphyses (wrists) } \\
\hline \multirow[t]{2}{*}{$\begin{array}{c}3-6 \\
6-9 \\
9-12 \\
12-15 \\
15-18\end{array}$} & $\begin{array}{l}38 \\
89 \\
92 \\
87 \\
86\end{array}$ & $\begin{array}{r}1 \\
5 \\
7 \\
12 \\
21\end{array}$ & $\begin{array}{l}45 \\
63 \\
97 \\
90 \\
90\end{array}$ & $\begin{array}{r}2 \\
2 \\
2 \\
7 \\
12\end{array}$ & $\begin{array}{r}(0) \\
(0) \\
(33) \\
(100) \\
(60)\end{array}$ & $\begin{array}{l}1 \\
1 \\
1 \\
1 \\
3\end{array}$ & $\begin{array}{l}58 \\
42 \\
56 \\
73 \\
50\end{array}$ & $\begin{array}{l}1 \\
1 \\
2 \\
3 \\
5\end{array}$ \\
\hline & \multicolumn{8}{|c|}{ Enlarged costo-chondral junctions } \\
\hline $\begin{array}{c}3-6 \\
6-9 \\
9-12 \\
12-15 \\
15-18\end{array}$ & $\begin{array}{l}89 \\
96 \\
93 \\
97 \\
95\end{array}$ & $\begin{array}{r}7 \\
15 \\
15 \\
19 \\
25\end{array}$ & $\begin{array}{c}39 \\
45 \\
83 \\
62 \\
(62)\end{array}$ & $\begin{array}{l}0 \\
2 \\
1 \\
5 \\
7\end{array}$ & $\begin{array}{l}(20) \\
(67) \\
(50) \\
(71) \\
(43)\end{array}$ & $\begin{array}{r}1 \\
2 \\
. \quad 2 \\
4 \\
4\end{array}$ & $\begin{array}{l}86 \\
90 \\
82 \\
86 \\
80\end{array}$ & $\begin{array}{l}3 \\
6 \\
8 \\
9 \\
8\end{array}$ \\
\hline
\end{tabular}


TABLE 4

CLINICAL DIAGNOSIS OF RICKETS-FREQUENCY AMONGST CHILDREN EXAMINED IN EACH CENTRE AT AGES 3-18 MONTHS AND CORRELATION WITH RADIOLOGICAL SIGNS (ACTIVE OR HEALED).

(NoTE.-For total children examined see Table 1.)

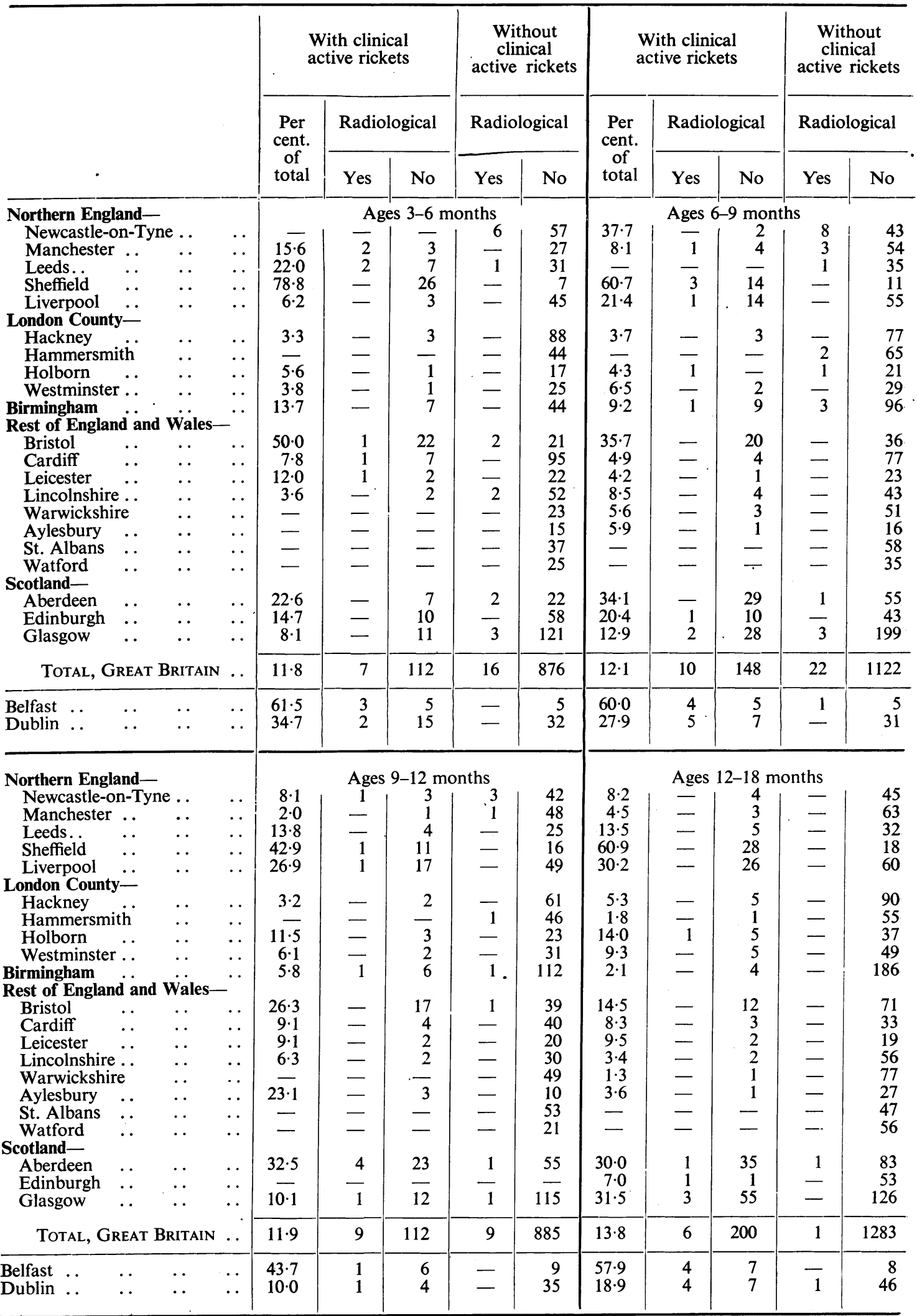


Taking these rates at their face value, that is to say, assuming that the effect of the personal equation of the clinicians is not important when the centres are aggregated into regional groups, it would appear that there are consistent differences between the clinically negative children in northern and southern towns. The northern and Scottish children not diagnosed as rachitic show higher proportions with delayed closure of the fontanelle and with enlarged epiphyses at the wrists, and those in the northern towns of England show higher proportions with enlarged costo-chondral junctions. Comparing the positive with the negative children, delayed closure of the fontanelle and craniotabes were present in higher proportions amongst the former in each region except London. Enlargement of epiphyses and costo-chondral junctions evidently formed the principal basis of the clinical diagnosis, although in the northern towns of England many children with these signs were not diagnosed as rachitic.

In Great Britain at ages 3-12 months, out of about 2600 clinically negative children examined, 50 recorded enlarged epiphyses at the wrists and
120 recorded enlarged costo-chondral junctions. Amongst the 2600 there were 39 said to have radiological rickets and of these 1 showed enlarged epiphyses and 5 enlarged costo-chondral junctions, the proportions not being significantly greater than amongst the radiologically negative children.

The average number of teeth recorded for the clinically and radiologically negative children showed no significant variation according to locality, and the comparison in the table below is based upon all the children examined at the age groups specified. In the first columns are given the numbers in this category who were examined and the mean number of teeth per child. The expected numbers of teeth in the radiologically positive children have then been calculated by multiplying the total children examined by the mean number of teeth for normal children of the corresponding age-group; and the expected total (E) compared with the observed total (O). A similar comparison is made for the children who were said to have clinical rickets but who showed no radiological signs.

\begin{tabular}{|c|c|c|c|c|c|c|}
\hline \multirow{2}{*}{$\begin{array}{c}\text { Age } \\
\text { (months) }\end{array}$} & \multicolumn{2}{|c|}{ Non-rachitic children } & \multicolumn{2}{|c|}{ Radiologically positive } & \multicolumn{2}{|c|}{$\begin{array}{l}\text { Clinically positive, but } \\
\text { radiologically negative }\end{array}$} \\
\hline & $\begin{array}{l}\text { No. } \\
\text { examined }\end{array}$ & $\begin{array}{l}\text { Average teeth } \\
\text { per child }\end{array}$ & E. & $\mathbf{O}$ & $\mathrm{E}$ & $\mathrm{O}$ \\
\hline $\begin{array}{r}6-9 \\
9-12 \\
12-15 \\
15-18\end{array}$ & $\begin{array}{r}1157 \\
929 \\
772 \\
562\end{array}$ & $\begin{array}{r}1 \cdot 22 \\
4 \cdot 27 \\
7 \cdot 27 \\
10 \cdot 89\end{array}$ & $\begin{array}{l}52 \\
85 \\
65 \\
76\end{array}$ & $\begin{array}{l}30 \\
87 \\
37 \\
74\end{array}$ & $\begin{array}{l}195 \\
517 \\
996 \\
839\end{array}$ & $\begin{array}{l}171 \\
499 \\
887 \\
720\end{array}$ \\
\hline Total $\ldots$ & 3420 & - & 278 & 228 & 2547 & 2277 \\
\hline
\end{tabular}

The 79 children with radiological signs had 228 teeth compared with 278 expected, the deficiency of 50 (18 per cent.) being 3 times its standard error and therefore significant. The 495 children with clinical but no radiological signs had 2277 teeth compared with 2547 expected, the deficiency of 270 (11 per cent.) being $5 \frac{1}{2}$ times its standard error and also significant. This shows that a clinical diagnosis of rickets in the absence of radiological signs was associated with delayed eruption of teeth, though not to such a pronounced degree as in the case of children with radiological rickets.

The age of commencing to walk was recorded for most of the children who had already started. Of 2632 aged 9-18 months 11 had started to walk before 9 months of age, the proportion being 3 per 1000 amongst the rachitic and 4 per 1000 amongst the non-rachitic, an insignificant difference. Of 1551 aged 12-18 months 323 had started to walk before 12 months, the proportion being about 21 per cent. alike for the rachitic and non-rachitic. Of 646 aged 15-18 months 2 out of 7 with radiological signs had started to walk before 15 months, compared with 49 out of 77 with clinical but no radiological signs (64 per cent.) and 404 out of 562 without any signs ( 72 per cent.), the proportions not differing significantly.
Finally, it is of interest to find whether the children who were said to have clinical rickets but showed no radiological evidence of it differed from the clinically and radiologically negative children as regards the amount of breast feeding. It has been shown in the preceding section that the radiologically positive children showed a deficiency averaging about 2 months in this duration, and it might be expected that the clinically positive but radiologically negative $(\mathrm{C}+\mathrm{R}-)$ would also show an appreciable deficiency compared with the clinically negative $(C-R-)$. The percentages who had never been breast fed compare as follows:-

$\begin{array}{clcc}\text { Age (months) } & \mathbf{R}+ & \mathbf{C}+\mathbf{R}- & \mathbf{C}-\mathbf{R}- \\ 6-9 & 27 \cdot 9 & 23 \cdot 1 \pm 3 \cdot 3 & 17 \cdot 3 \pm 1 \cdot 1 \\ 9-12 & 40 \cdot 0 & 25 \cdot 6 \pm 4 \cdot 0 & 19 \cdot 2 \pm 1 \cdot 3 \\ 12-18 & 43 \cdot 7 & 20 \cdot 1 \pm 2 \cdot 7 & 19 \cdot 8 \pm 1 \cdot 1\end{array}$

At ages 6-12 months the proportions never breast fed were slightly higher in the $\mathbf{C}+\mathbf{R}-$ group than in the normal children, but the differences are of doubtful significance. Amongst those who had been breast fed at some time the $\mathrm{C}+\mathrm{R}$ - group showed no appreciable deficit in average duration of breast feeding in months, as shown below:-

$\begin{array}{cccc}\text { Age (months) } & \mathbf{R}+ & \mathbf{C}+\mathbf{R}- & \mathbf{C}-\mathbf{R}- \\ 6-9 & 2 \cdot 61 & 4 \cdot 31 & 4.25 \\ 9-12 & 3.21 & 5 \cdot 24 & 5.29 \\ 12-18 & 5 \cdot 17 & 5.47 & 5.55\end{array}$




\section{Summary of Section III}

Amongst 4818 children aged 3-18 months examined in Great Britain 604 were said to have clinical active rickets and another 144 to have had rickets previously. The proportion with ' active rickets' was $12 \frac{1}{2}$ per cent. and varied little with age. The estimated incidence rate up to 6 months of age was 13 per cent. compared with $2 \cdot 4$ per cent. diagnosed as rachitic on radiological grounds. There was great local variation in the proportions. diagnosed as clinically positive, which ranged at 6-9 months from 3 per cent. in London to 60 per cent. or more in Sheffield and Belfast. 'In Liverpool, London and the Scottish towns the proportion increased with advancing age, whereas in the Midland and other southern towns of England it decreased.
The correlation between the clinical and radiological diagnoses was very poor in Great Britain. Less than half of the children said to have active rickets on radiological grounds were included amongst the clinically rachitic, and only 5 per cent. of all children said to be clinically rachitic showed radiological signs compared with 1 per cent. of the clinically negative. The Irish children showed a more consistent correlation, 30 per cent. of the clinically positive showing radiological signs compared with 1 per cent. of the clinically negative.

The association between closure of the anterior fontanelle, cranio-tabes, enlarged epiphyses at the wrists, enlarged costo-chondral junctions, number of teeth and age at which the child started to walk, on the one hand, and the clinical and radiological diagnoses of rickets on the other is examined.

APPENDIX A

RADIOLOGICAL AND CLINICAL DIAGNOSIS OF RICKETS IN CHILDREN EXAMINED IN EACH CENTRE AT AGES OTHER THAN 3-18 MONTHS

\begin{tabular}{|c|c|c|c|c|c|c|c|c|c|c|}
\hline & & & & \multirow{4}{*}{$\begin{array}{c}\text { Ages } \\
\text { under } \\
3 \\
\text { months } \\
(1)\end{array}$} & \multicolumn{6}{|c|}{ Ages 18 months and over } \\
\hline & & & & & \multirow{3}{*}{$\underset{\text { group }}{\text { Age }}$} & \multirow{3}{*}{$\begin{array}{l}\text { No. } \\
\text { exam- } \\
\text { ined }\end{array}$} & \multicolumn{2}{|c|}{$\begin{array}{l}\text { With clinical } \\
\text { active rickets }\end{array}$} & \multicolumn{2}{|c|}{$\begin{array}{l}\text { Without clinical } \\
\text { active rickets }\end{array}$} \\
\hline & & & & & & & \multicolumn{2}{|c|}{ Radiologically } & \multicolumn{2}{|c|}{ Radiologically } \\
\hline & & & & & & & Positive & Negative & Positive & Negative \\
\hline \multirow{2}{*}{\multicolumn{2}{|c|}{$\begin{array}{l}\text { Newcastle-on-Tyne } \\
\text { Manchester } \quad . .\end{array}$}} & .. & .. & - & $18-24$ & 4 & - & - & - & 4 \\
\hline & & $\cdots$ & .. & - & $18-30$ & 8 & - & - & - & 8 \\
\hline Leeds $\quad$. & 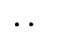 & .. & .. & 1 & $18-30$ & 2 & - & - & - & 2 \\
\hline Sheffield ... & $\ldots$ & .. & .. & 1 & $18-24$ & 5 & - & 4 & - & 1 \\
\hline \multirow{2}{*}{$\begin{array}{l}\text { Liverpool } \\
\text { Hackney .. }\end{array}$} & $\ldots$ & $\begin{array}{l}. . \\
\end{array}$ & $\ldots$ & - & $18-30$ & 12 & - & 3 & - & 9 \\
\hline & $\because$. & $\because$ & . & - & $18-30$ & 17 & - & 4 & - & 13 \\
\hline Hammersmith & $\because$. & $\because$ & .. & - & $18-24$ & 3 & - & - & - & 3 \\
\hline Holborn .. & $\ldots$ & .. & .. & 1 & $18-24$ & 7 & - & 1 & - & 6 \\
\hline & $\ldots$ & .. & .. & - & $18-24$ & 14 & - & 1 & - & 13 \\
\hline & .. & .. & $\because$ & - & $18-30$ & 14 & - & 1 & - & 13 \\
\hline $\begin{array}{l}\text { Birmingham } \\
\text { Cardiff ... }\end{array}$ & .. & .. & .. & 2 & $18-30$ & 3 & - & - & - & 3 \\
\hline Leicester .. & .. & .. & .. & 1 & $18-24$ & 1 & $1(2)$ & - & - & - \\
\hline \multirow{2}{*}{$\begin{array}{l}\text { Lincolnshire } \\
\text { Warwickshire }\end{array}$} & $\ldots$ & $\therefore$ & .. & 1 & $18-24$ & 6 & & - & 二 & 6 \\
\hline & 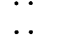 & $\because$ & $\because$ & - & $18-24$ & 6 & - & - & - & 6 \\
\hline $\begin{array}{l}\text { Warwickshire } \\
\text { Aylesbury }\end{array}$ & .. & .. & .. & 1 & $18-30$ & 3 & - & - & - & 3 \\
\hline St. Albans & $\ldots$ & $\therefore$ & $\therefore$ & 1 & $18-24$ & 4 & - & - & - & 4 \\
\hline Watford .. & $\ldots$ & $\ddot{.}$ & .. & - & $18-30$ & 13 & - & - & - & 13 \\
\hline Edinburgḥ & 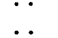 & $\because$ & 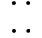 & - & $18-21$ & 41 & $1(2)$ & 1 & - & 39 \\
\hline Glasgow .. & . & .. & .. & 1 & $18-24$ & 17 & $1(3)$ & 2 & - & 14 \\
\hline De & $\cdots$ & $\cdots$ & .. & & $24-30$ & 2 & & & & 2 \\
\hline Belfast $\quad$. & . & .. & .. & - & $18-24$ & 5 & $1(3)$ & 2 & - & 2 \\
\hline Dub̉lin $\quad \cdots$ & . & . & .. & 1 & $24-42$ & 3 & - & 1 & - & 2 \\
\hline $\begin{array}{cc}0 . \\
, \quad & \ldots\end{array}$ & $\because$. & 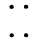 & 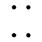 & & $24-30$ & 1 & 二 & 二 & 二 & 1 \\
\hline
\end{tabular}

\section{Notes.}

(1) All clinically and radiologically negative.

(2) Healed rickets.

(3) Radiologists were not agreed as to whether active or healed (see Appendix B).

There were also 2 children at Leicester and 1 at Hackney for whom the records were incomplete as to age, etc., and these have been omitted. 


\section{APPENDIX B}

DETAILS OF RECORDED OPINIONS OF THE RADIOLOGISTS REGARDING THE CHILDREN CLASSIFIED AS RADIOLOGICALLY POSITIVE IN THE TABLES

\begin{tabular}{|c|c|c|c|c|c|c|c|c|c|}
\hline & & \multirow{2}{*}{$\begin{array}{c}\text { Age } \\
\text { (months) }\end{array}$} & \multicolumn{3}{|c|}{ Is rickets present? } & \multicolumn{3}{|c|}{ Active or Old (healed)? } & \multirow{2}{*}{$\begin{array}{l}\text { How } \\
\text { classed }\end{array}$} \\
\hline & & & A & B & $\mathrm{C}$ & A & $\mathbf{B}$ & C & \\
\hline $\begin{array}{l}\text { Newcastle-on- } \\
\text { Tyne. }\end{array}$ & & $\begin{array}{r}4 \\
4 \\
4 \\
5 \\
5 \\
5 \\
6 \\
6 \\
6 \\
6 \\
7 \\
7 \\
8 \\
8 \\
10 \\
10 \\
11 \\
11\end{array}$ & $\begin{array}{c}\text { Yes } \\
\text { Yes } \\
\text { Yes } \\
\text { Yes } \\
\text { Yes } \\
\text { Yes } \\
\text { Yes? Mild } \\
\text { Yes? Mild } \\
\text { Yes? Mild } \\
\text { No } \\
\text { Yes } \\
\text { Yes? Mild } \\
\text { Yes } \\
\text { Yes } \\
\text { Yes. Mild } \\
\text { Yes } \\
\text { Yes } \\
\text { Yes }\end{array}$ & $\begin{array}{l}\text { Yes } \\
\text { Yes } \\
\text { Yes } \\
\text { Yes } \\
\text { Yes } \\
\text { Yes } \\
\text { Yes } \\
\text { Yes } \\
\text { Yes } \\
\text { Early } \\
\text { Yes } \\
\text { Yes } \\
\text { Yes } \\
\text { Yes } \\
\text { Yes } \\
\text { Yes } \\
\text { Yes }\end{array}$ & $\begin{array}{l}\text { Yes } \\
\text { No } \\
\text { Yes } \\
\text { Yes } \\
\text { Yes } \\
\text { No } \\
\text { Yes } \\
\text { No } \\
\text { Yes } \\
\text { Yes } \\
\text { No } \\
\text { Yes } \\
\text { No } \\
\text { No } \\
\text { Yes } \\
\text { Yes } \\
\text { Yes }\end{array}$ & $\begin{array}{l}\text { Old } \\
\text { Old } \\
\text { Old } \\
\text { Old } \\
\text { Old } \\
\text { Old } \\
\text { Old } \\
\text { Old } \\
\text { Old } \\
\text { Old } \\
\text { Old } \\
\text { Old } \\
\text { Old } \\
\text { Old } \\
- \\
\text { Old } \\
\text { Old }\end{array}$ & $\begin{array}{c}\text { Healing } \\
- \\
\overline{-} \\
\text { Healed } \\
\text { Healing } \\
= \\
= \\
= \\
= \\
= \\
-\end{array}$ & $\begin{array}{l}- \\
= \\
= \\
= \\
= \\
\text { Active } \\
= \\
= \\
= \\
= \\
-\end{array}$ & $\begin{array}{c}\mathbf{H} \\
\mathbf{H} \\
\mathbf{H} \\
\mathbf{H} \\
\mathbf{H} \\
\mathbf{H} \\
\mathbf{H} \\
\mathbf{H} \\
\mathbf{H} \\
\text { Active } \\
\mathbf{H} \\
\mathbf{H} \\
\mathbf{H} \\
\mathbf{H} \\
\mathbf{H} \\
\mathbf{H} \\
\mathbf{H} \\
\mathbf{H}\end{array}$ \\
\hline Manchester & . & $\begin{array}{l}4 \\
5 \\
7 \\
7 \\
8 \\
7 \\
9\end{array}$ & $\begin{array}{l}\text { Yes? Mild } \\
\text { Yes? Mild } \\
\text { Yes? Mild } \\
\text { Yes. Mild } \\
\text { ? Mild } \\
\text { Yes? Mild } \\
\text { Yes? Slight }\end{array}$ & $\begin{array}{l}\text { Yes } \\
\text { Yes } \\
\text { Yes } \\
\text { Yes } \\
\text { Yes } \\
\text { Early } \\
\text { Yes }\end{array}$ & $\begin{array}{c}\text { No } \\
\text { Possibly } \\
\text { No } \\
\text { Yes } \\
\text { No } \\
\text { No } \\
\text { Yes }\end{array}$ & $\begin{array}{l}\text { Active } \\
\text { Active } \\
\text { Active } \\
\text { Active } \\
\text { Active } \\
\text { Active } \\
\text { Old }\end{array}$ & $\begin{array}{l}\text { Healing } \\
\text { Active } \\
\text { Healing } \\
\text { Healing } \\
\text { Healing } \\
\text { ? Healing } \\
\text { Active }\end{array}$ & $\begin{array}{l}\text { Healed } \\
\text { Healing } \\
- \\
\text { Active }\end{array}$ & $\begin{array}{c}\mathbf{H} \\
\text { Active } \\
\mathbf{H} \\
\mathbf{H} \\
\mathbf{H} \\
\text { Active } \\
\text { Active }\end{array}$ \\
\hline Leeds $\quad \ldots$ & . & $\begin{array}{l}4 \\
5 \\
5 \\
7\end{array}$ & $\begin{array}{c}\text { Yes. Slight } \\
\text { Yes } \\
\text { Yes. Slight } \\
\text { Yes }\end{array}$ & $\begin{array}{l}\text { Yes } \\
\text { Yes } \\
\text { Yes } \\
\text { Yes }\end{array}$ & $\begin{array}{l}\text { No } \\
\text { Yes } \\
\text { Yes } \\
\text { Yes }\end{array}$ & $\begin{array}{l}\text { Old } \\
\text { Old } \\
\text { Old } \\
\text { Old }\end{array}$ & E & $\begin{array}{l}- \\
-\end{array}$ & $\begin{array}{l}\mathrm{H} \\
\mathrm{H} \\
\mathrm{H} \\
\mathrm{H}\end{array}$ \\
\hline Sheffield .. & . & $\begin{array}{l}6 \\
7 \\
7 \\
9\end{array}$ & $\begin{array}{l}\text { Yes } \\
\text { Yes } \\
\text { Yes? } \\
\text { Yes }\end{array}$ & $\begin{array}{l}\text { Blurred } \\
\text { Yes } \\
\text { Yes } \\
\text { Severe }\end{array}$ & $\begin{array}{l}\text { Yes } \\
\text { No } \\
\text { No } \\
\text { Yes }\end{array}$ & $\begin{array}{l}\text { Old } \\
\text { Old } \\
\text { No } \\
\text { Healing }\end{array}$ & $\frac{\overline{-}}{\overline{-}}$ & $\begin{array}{c}\text { Active } \\
- \\
\text { Active }\end{array}$ & $\begin{array}{c}\text { Active } \\
\mathbf{H} \\
\mathbf{H} \\
\text { Active }\end{array}$ \\
\hline Liverpool & . & $\begin{array}{r}6 \\
11\end{array}$ & $\begin{array}{c}\text { Yes? Slight } \\
\text { Yes }\end{array}$ & $\begin{array}{l}\text { Yes } \\
\text { Yes }\end{array}$ & $\begin{array}{l}\text { Yes? } \\
\text { Yes }\end{array}$ & $\begin{array}{l}\text { Active } \\
\text { Active }\end{array}$ & $\begin{array}{l}\text { Healing } \\
\text { Healing }\end{array}$ & $\begin{array}{l}\text { Active } \\
\text { Healing }\end{array}$ & $\begin{array}{c}\text { Active } \\
\text { H }\end{array}$ \\
\hline Hammersmith & . & $\begin{array}{r}6 \\
7 \\
11\end{array}$ & $\begin{array}{l}\text { Yes } \\
\text { Yes } \\
\text { Yes }\end{array}$ & $\begin{array}{l}\text { Yes } \\
\text { Yes } \\
\text { Early }\end{array}$ & $\begin{array}{l}\text { No } \\
\text { No } \\
\text { No }\end{array}$ & $\begin{array}{l}\text { Old } \\
\text { Old } \\
\text { Old }\end{array}$ & - & - & $\begin{array}{l}\mathbf{H} \\
\mathbf{H} \\
\mathbf{H}\end{array}$ \\
\hline Holborn . & . & $\begin{array}{r}6 \\
8 \\
16\end{array}$ & $\begin{array}{c}\text { Yes? } \\
\text { Yes? } \\
\text { Yes? Mild }\end{array}$ & $\begin{array}{l}\text { Yes } \\
\text { Yes } \\
\text { Yes } \\
\text { Slight }\end{array}$ & $\begin{array}{l}\text { Yes } \\
\text { No } \\
\text { No }\end{array}$ & $\begin{array}{l}\text { Old } \\
\text { Old } \\
\text { Old }\end{array}$ & - & $\begin{array}{c}\text { Healing } \\
-\end{array}$ & $\begin{array}{l}\mathbf{H} \\
\mathbf{H} \\
\mathbf{H}\end{array}$ \\
\hline Birmingham & . & $\begin{array}{l}6 \\
6 \\
7 \\
8 \\
9 \\
9\end{array}$ & $\begin{array}{c}\text { Yes } \\
\text { Yes } \\
\text { Yes? Slight } \\
\text { Yes } \\
\text { Yes. Slight } \\
\text { Yes? }\end{array}$ & $\begin{array}{c}\text { Yes } \\
\text { Yes } \\
\text { Yes } \\
\text { Yes and } \\
\text { Scurvy } \\
\text { Yes } \\
\text { Yes }\end{array}$ & $\begin{array}{l}\text { Yes } \\
\text { No } \\
\text { No } \\
\text { No- } \\
\text { Scurvy } \\
\text { Yes? } \\
\text { No }\end{array}$ & $\begin{array}{l}\text { Healing } \\
\text { Old } \\
\text { Old } \\
\text { Healing } \\
\\
\text { Old } \\
\text { Healed }\end{array}$ & $\begin{array}{l}-\overline{-} \\
\text { Healing } \\
\qquad- \\
\text { Healing } \\
\text { Healing }\end{array}$ & $\begin{array}{c}\text { Active } \\
- \\
- \\
- \\
-\end{array}$ & $\begin{array}{l}\mathbf{H} \\
\mathbf{H} \\
\mathbf{H} \\
\mathbf{H} \\
\mathbf{H} \\
\mathbf{H}\end{array}$ \\
\hline Bristol $\ldots$ & . & $\begin{array}{r}4 \\
4 \\
4 \\
10\end{array}$ & $\begin{array}{l}\text { Yes? } \\
\text { Yes? } \\
\text { Yes? } \\
\text { Yes }\end{array}$ & $\begin{array}{l}\text { Yes } \\
\text { Yes } \\
\text { Yes } \\
\text { Yes }\end{array}$ & $\begin{array}{l}\text { No } \\
\text { No } \\
\overline{\text { Yes }}\end{array}$ & $\begin{array}{l}\text { Old } \\
\text { Old } \\
\text { Old } \\
-\end{array}$ & - & - & $\begin{array}{l}\mathbf{H} \\
\mathbf{H} \\
\mathbf{H} \\
\mathbf{H}\end{array}$ \\
\hline Cardiff $\quad \ldots$ & . & 5 & Yes? Slight & Yes & No & Old & Healing & - & $\mathbf{H}$ \\
\hline Leicester & . & 5 & Yes? & Yes & - & Old & ? Healing & - & $\mathbf{H}$ \\
\hline
\end{tabular}


APPENDIX B-continued

\begin{tabular}{|c|c|c|c|c|c|c|c|c|c|}
\hline & & \multirow{2}{*}{$\begin{array}{c}\text { Age } \\
\text { (months) }\end{array}$} & \multicolumn{3}{|c|}{ Is rickets present? } & \multicolumn{3}{|c|}{ Active or Old (healed)? } & \multirow{2}{*}{$\begin{array}{l}\text { How } \\
\text { classed }\end{array}$} \\
\hline & & & A & B & $\mathrm{C}$ & $\mathbf{A}$ & B & C & \\
\hline Lincolnshire & $\cdots$ & $\begin{array}{l}4 \\
5\end{array}$ & $\begin{array}{l}\text { Yes } \\
\text { No }\end{array}$ & Early & $\begin{array}{l}\text { Yes? } \\
\text { Slight? }\end{array}$ & Old & - & - & $\begin{array}{l}\mathrm{H} \\
\mathrm{H}\end{array}$ \\
\hline Aberdeen & . & $\begin{array}{r}4 \\
4 \\
7 \\
9 \\
10 \\
11 \\
11 \\
11 \\
13 \\
15\end{array}$ & $\begin{array}{c}\text { Yes } \\
\text { Yes? } \\
\text { Yes. Slight } \\
\text { Yes } \\
\text { No } \\
\text { Yes } \\
\text { Yes? } \\
\text { Yes. Slight } \\
\text { Yes } \\
\text { Yes. Slight }\end{array}$ & $\begin{array}{l}\text { Yes } \\
\text { Yes } \\
\text { Yes } \\
\text { Yes } \\
\text { Yes } \\
\text { Yes } \\
\text { Yes } \\
\text { Yes } \\
\text { Early } \\
\text { Yes }\end{array}$ & $\begin{array}{l}\text { Yes } \\
\text { No } \\
\text { Yes } \\
\text { Yes } \\
\text { Yes } \\
\text { Yes } \\
\text { No } \\
\text { Yes } \\
\text { ? Early } \\
\text { Yes }\end{array}$ & $\begin{array}{l}\text { Old } \\
\text { Old } \\
\text { Old } \\
- \\
\overline{\text { Old }} \\
\text { Old } \\
\text { Old } \\
\overline{\text { Old }}\end{array}$ & $\begin{array}{l}- \\
\text { Active } \\
\text { Active } \\
\text { Active } \\
\text { Active } \\
- \\
\text { Active } \\
\text { Active }\end{array}$ & $\begin{array}{l}- \\
\text { Active } \\
\text { Active } \\
\text { Active } \\
\text { Active } \\
\text { Active } \\
\text { Active }\end{array}$ & $\begin{array}{c}\mathrm{H} \\
\mathrm{H} \\
\text { Active } \\
\text { Active } \\
\text { Active } \\
\text { Active } \\
\mathbf{H} \\
\text { Active } \\
\text { H } \\
\text { Active }\end{array}$ \\
\hline Edinburgh & .. & $\begin{array}{r}7 \\
12\end{array}$ & $\begin{array}{l}\text { Yes? } \\
\text { Yes }\end{array}$ & $\begin{array}{l}\text { Yes } \\
\text { Yes }\end{array}$ & $\underset{\text { Yes }}{\text { Yes. Slight }}$ & $\begin{array}{c}\text { Old } \\
\text { Healing }\end{array}$ & $\begin{array}{l}\text { Healing } \\
\text { Active }\end{array}$ & $\begin{array}{l}\text { Active } \\
\text { Active }\end{array}$ & $\underset{\text { Active }}{\mathrm{H}}$ \\
\hline Glasgow .. & $\cdots$ & $\begin{array}{r}5 \\
5 \\
5 \\
6 \\
6 \\
8 \\
7 \\
8 \\
9 \\
9 \\
12 \\
14 \\
17\end{array}$ & $\begin{array}{l}\text { Yes } \\
\text { Yes? } \\
\text { Yes } \\
\text { Yes } \\
\text { Yes } \\
\text { Yes } \\
\text { Yes } \\
\text { Blurred? } \\
\text { Yes } \\
\text { Yes } \\
\text { Yes } \\
\text { Yes? }\end{array}$ & $\begin{array}{c}\text { Yes } \\
\text { Blurred } \\
\text { Yes } \\
\text { Yes } \\
\text { Yes, mild } \\
\text { Yes } \\
\text { Yes } \\
\text { Yes } \\
\text { Yes } \\
\text { Yes } \\
\text { Yes } \\
\text { Yes } \\
\text { Yes }\end{array}$ & $\begin{array}{l}\text { No } \\
\text { Yes? } \\
\text { Yes } \\
\text { No } \\
\text { Yes } \\
\text { Yes } \\
\text { Yes } \\
\text { No } \\
\text { Yes? } \\
\text { Yes } \\
\text { Yes } \\
\text { Yes } \\
\text { Yes? }\end{array}$ & $\begin{array}{l}\overline{-} \\
\overline{-} \\
\text { ? Healed } \\
\text { Active } \\
\text { Active } \\
\overline{-} \\
\text { Healing } \\
\text { Active } \\
\text { Active } \\
\text { Healed? }\end{array}$ & $\begin{array}{l}\text { ? Healed } \\
\text { Early } \\
\text { Healing } \\
\text { Healed } \\
- \\
\text { Healing } \\
\text { Healing } \\
\text { Healed } \\
\text { Healing } \\
\text { Active } \\
-\end{array}$ & $\begin{array}{l}-\overline{-} \\
\text { Early } \\
\text { Healed } \\
\text { Active } \\
\text { Active } \\
\text { Healed } \\
\text { Active } \\
\text { Active } \\
-\end{array}$ & $\begin{array}{c}\text { Active } \\
\text { H } \\
\text { Active } \\
\text { H } \\
\text { H } \\
\text { Active } \\
\text { Active } \\
\text { H } \\
\text { H } \\
\text { Active } \\
\text { H } \\
\text { Active } \\
\text { H }\end{array}$ \\
\hline Dublin .. & $\cdots$ & $\begin{array}{r}3 \\
5 \\
6 \\
6 \\
7 \\
8 \\
8 \\
9 \\
12 \\
13 \\
15 \\
17 \\
17\end{array}$ & $\begin{array}{c}\text { Yes } \\
\text { Yes } \\
\text { Yes, Mild } \\
\text { Yes } \\
\text { Yes } \\
\text { Yes } \\
\text { Yes } \\
\text { Yes, Mild } \\
\text { Yes } \\
\text { Yes } \\
\text { Yes, Slight } \\
\text { Yes } \\
\text { Yes }\end{array}$ & $\begin{array}{l}\text { Yes* } \\
\text { Yes } \\
\text { Early } \\
\text { Yes } \\
\text { Yes } \\
\text { Yes } \\
\text { Yes } \\
\text { Yes } \\
\text { Yes } \\
\text { Yes } \\
\text { Early } \\
\text { Yes } \\
\text { Yes }\end{array}$ & $\begin{array}{c}\text { No } \\
\text { Yes } \\
\text { Blurred. } \\
\text { Yes } \\
\text { Yes } \\
\text { Yes? } \\
\text { Yes } \\
\text { Yes } \\
\text { No } \\
\text { Yes } \\
\text { No } \\
\text { Yes } \\
\text { Yes }\end{array}$ & $\begin{array}{c}\text { Old } \\
\text { Healing } \\
\text { Old } \\
\text { Old } \\
\text { Old } \\
\text { Old } \\
\text { Old } \\
\text { Old } \\
\text { Old } \\
\text { Old } \\
\text { Old. } \\
\text { Old } \\
\text { Healing }\end{array}$ & $\begin{array}{c}- \\
- \\
- \\
\overline{-} \\
\overline{-} \\
\text { Healing } \\
\text { Healing } \\
-\end{array}$ & $\begin{array}{l}\overline{-} \\
\overline{-} \\
\text { Active } \\
\text { Active } \\
\overline{-} \\
\text { Active } \\
\overline{-} \\
\text { Active } \\
\text { Active } \\
\text { Active }\end{array}$ & $\begin{array}{l}- \\
z \\
- \\
z \\
z \\
- \\
- \\
-\end{array}$ \\
\hline Belfast .. & . & $\begin{array}{r}4 \\
5 \\
5 \\
6 \\
7 \\
7 \\
7 \\
8 \\
10 \\
12 \\
13 \\
14 \\
15\end{array}$ & $\begin{array}{l}\text { Yes } \\
\text { Yes } \\
\text { Yes } \\
\text { Yes } \\
\text { Yes } \\
\text { Yes } \\
\text { Yes } \\
\text { Yes } \\
\text { Yes } \\
\text { Yes } \\
\text { Yes } \\
\text { Yes } \\
\text { Yes }\end{array}$ & $\begin{array}{l}\text { Yes } \\
\text { Yes } \\
\text { Yes } \\
\text { Yes } \\
\text { ? Slight } \\
\text { Yes } \\
\text { Yes } \\
\text { Yes } \\
\text { Yes } \\
\text { Slight } \\
\text { Yes } \\
\text { Yes } \\
\text { Yes }\end{array}$ & $\begin{array}{l}\text { Yes } \\
\text { Yes } \\
\text { Yes } \\
\text { Yes } \\
\text { ? Early } \\
\text { Yes } \\
\text { Yes } \\
\text { Yes } \\
\text { Yes } \\
\text { ? Early } \\
\text { Yes } \\
\text { Yes } \\
\text { Yes }\end{array}$ & $\begin{array}{c}\text { Healing } \\
\text { Healing } \\
\text { Healing } \\
\text { Healing } \\
\text { Active } \\
\text { Healing } \\
\text { Healing } \\
\text { Healing } \\
\text { Active } \\
\text { Active } \\
\text { Healing } \\
\text { Healing }\end{array}$ & $\begin{array}{l}- \\
- \\
z \\
- \\
z \\
- \\
- \\
-\end{array}$ & $\begin{array}{c}\text { Active } \\
\text { Active } \\
\text { Active } \\
\text { Active } \\
\text { Active } \\
\text { Active } \\
\text { Active } \\
\text { Active } \\
\text { Active } \\
\text { Active } \\
\text { Active }\end{array}$ & $\begin{array}{l}- \\
- \\
- \\
- \\
- \\
- \\
- \\
-\end{array}$ \\
\hline $\begin{array}{l}\text { Ages: } 18 \text { mor } \\
\text { and over- } \\
\text { Leicester } \\
\text { Edinburgh } \\
\text { Glasgow .. } \\
\text { Belfast .. }\end{array}$ & $\begin{array}{l}\therefore \\
. \\
. \\
.\end{array}$ & $\begin{array}{l}18 \\
18 \\
18 \\
18\end{array}$ & $\begin{array}{l}\text { Yes } \\
\text { Yes } \\
\text { Yes } \\
\text { Yes }\end{array}$ & $\begin{array}{l}\text { Yes } \\
\text { Yes } \\
\text { Yes } \\
\text { Yes }\end{array}$ & $\begin{array}{l}\text { Yes } \\
\text { Yes } \\
\text { Yes } \\
\text { Yes }\end{array}$ & $\begin{array}{c}\text { Healing } \\
\text { Old } \\
\text { Healing }\end{array}$ & $\begin{array}{l}\text { Healing } \\
\text { Healing } \\
\text { - }\end{array}$ & $\begin{array}{c}\text { Healing } \\
\text { Healing } \\
\text { Active } \\
\text { Active }\end{array}$ & $\begin{array}{l}\mathrm{H} \\
\mathrm{H} \\
\mathrm{H} \\
-\end{array}$ \\
\hline
\end{tabular}

Notes.-No entry in the A, B, C, columns indicates absence of any statement by the radiologist in question.

' $\mathrm{H}$ ' in the final column means that classification has been made to Healed rickets. For Belfast and Dublin no classification into Active and Healed has been attempted owing to the inconsistency for a large proportion of the diagnoses on this point. * Also congenital syphilis and arthritis of elbow. 


\section{Discussion *}

Out of a total of 5283 children examined in 23 centres in the British Isles there were 106 reported as showing radiological evidence of rickets. The small number of positive findings, while gratifying from the public health aspect, afforded too small a group to permit of much dissection into different subdivisions as regards type of feeding, type of vitamin D administration and other factors. Moreover, the reports concerning these points were based upon verbal statements by the mothers, for the most part unchecked, and therefore unreliable from a scientific point of view. The investigation provides a broad picture of the incidence of rickets in the groups of children examined; it would not be fair to examine the results in too much detail.

From this broad aspect it is shown by Dr. Stocks that in Great Britain the rate of incidence of rickets diagnosed radiologically for children between three and eighteen months of age was $2 \frac{1}{2}$ per cent. before six months of age, 4 per cent. during the first year of life and negligible over this age. Comparison with the few previous surveys which can be regarded as at all comparable affords no evidence of any wartime increase in radiological rickets.

The clinical diagnosis of rickets showed great variability, the rate recorded (for active rickets) being nil in St. Albans and Watford and 61 per cent. in Sheffield. The correlation between the clinical and radiological diagnosis was very poor in Great Britain where only a small proportion of the clinically positive cases were confirmed radiologically. It has been suggested that this result, far from throwing doubt upon the value of clinical diagnosis, may be interpreted as indicating the failure of radiological diagnosis to detect all the cases of rickets. But this view can be refuted by pointing out that the clinical methods of diagnosis failed to pick out half of the cases of active rickets diagnosed by radiology.

Reasons for the difficulties in clinical diagnosis and in radiological diagnosis, especially in the healing stage, have already been set out. Most observers are agreed that the severe type of rickets with deforming bone changes has almost disappeared from Great Britain and with this disappearance the clinical conception of rickets must undergo some modification. A disturbance of calcification sufficient to indicate active rickets in an $\mathrm{x}$-ray picture but not detected by the recognised clinical standards may need a new terminology. It is possible that chemical investigation, e.g. of blood phosphatase, will prove of value in this new aspect of an old nutritional problem and there is need for more extensive planned investigations to include biochemical tests.

The returns have been examined as regards the value of breast feeding and of vitamin $\mathrm{D}$ administration in the prevention of rickets, but with only 106 positive cases it is not possible to analyse the results in detail for these points. Nevertheless, certain observations may be made on these two aspects.

(a) Breast feeding and rickets. It must be re-

* See note on page 46. peated that the answers to this part of the questionnaire were made by the mothers, usually unchecked and not recorded in any detail. Dr. Stocks reports that among the radiologically negative children $81 \frac{1}{2}$ per cent. have been breast fed, whilst among the radiologically positive children only 69 per cent. have been breast fed. The findings, however, confirm what has already been known by paediatricians for many years, namely, that breast feeding alone, important as it is in the prevention of morbidity and mortality, cannot be relied upon to prevent the occurrence of rickets. The mother's diet must be adequate in vitamin $\mathrm{D}$, the child must not be growing too fast and breast feeding must be continued for a period neither too short nor too long if rickets is to be avoided and even in these ideal circumstances a vitamin $D$ supplement should be given. It must be realised that any rapidly growing infant is on the verge of rickets, so to speak, and in this border-line state the diagnosis is virtually impossible. Importance must be attached to the statement that amongst the radiologically positive children aged 3-9 months only 3, 2 of rather doubtful diagnosis, out of 70 (4 per cent.) had been entirely breast fed as compared with 441 out of 2363 (19 per cent.) of the control group of radiologically negative children of the same ages. Moreover, the duration of breast feeding was significantly longer in those children who had escaped rickets. To sum up, the report affords evidence that rickets is more likely to appear in the artificially fed than in the breast-fed baby.

(b) Vitamin D and rickets. Replies on the prophylactic use of vitamin $D$ in whatever form are subject to the same considerations as for breast feeding. Analysis in terms of the duration of vitamin D prophylaxis and the dosage has not been attempted and therefore it would be wrong to attach too much importance to the results reported. It is shown that of the children who were free from rickets on radiological examination $85 \frac{1}{2}$ per cent. had received codliver oil or other vitamin D preparation, whereas the figure for those showing radiological evidence of rickets was only 73 per cent. Note must be taken of the fact that 73 per cent. of the children with rickets were stated to have received some form of vitamin $\mathbf{D}$ prophylaxis. This investigation was conducted before the new official 'cod-liver oil' preparation with the increased vitamin $\mathrm{D}$ content had become available so that even the then official dosage of the national oil may have been insufficient to prevent rickets. It has been said with some truth that a common cause of rickets is the popular ' cod-liver oil and malt' because the amount of cod-liver oil contained in the usual dose of the preparation administered is quite inadequate to prevent rickets and a false security is engendered by its use. Scientific evidence has clearly shown that adequate vitamin $\mathbf{D}$ administered in an adequate dosage and in a suitable form will prevent rickets.

To sum up, this investigation was planned to ascertain whether or not there was any war-time 
change in the incidence of rickets. In so far as there were pre-war investigations at all comparable it would appear that, taking a broad view, there is no evidence of any increase in the incidence of rickets. Detailed studies of individual areas are not considered advisable in view of various difficulties already set out. Nevertheless, certain cases in the groups examined did show an incidence which still gives scope for better prophylactic measures of which a more extensive use of the Government's national ' cod-liver oil' compound is certainly an important one.

The report calls attention to the difficulties associated with the early diagnosis of rickets and the present-day position of the nutritional problem of adequate calcification of bone in the active growing child.
Acknowledgments and thanks

This investigation necessitated the goodwill and hard work of many individuals and the British Paediatric Association wishes to record its gratitude for all the willing help received. As far as possible the names of those who assisted are set out in the official report, Appendix 4.

In addition, grateful thanks are due to Officers of the Ministry of Health and Department of Health for Scotland for assistance and financial help; to Dr. Percy Stocks, medical statistician to the General Register Office, for his statistical analysis, and to the three radiologists, Dr. S. Whately Davidson, Newcastle; Dr. C. G. Teall, Birmingham; and Dr. D. Campbell Suttie, Glasgow; who undertook the arduous task of examining and reporting on approximately 5000 skiagrams.

\section{APPENDIX I}

ENGLAND AND WALES

\begin{tabular}{|c|c|c|c|c|c|c|c|}
\hline \multicolumn{3}{|c|}{ Area } & \multicolumn{2}{|l|}{$\begin{array}{l}\text { Paediatrician } \\
\text { responsible }\end{array}$} & \multirow{2}{*}{$\begin{array}{l}\begin{array}{l}\text { No. of } \\
\text { children }\end{array} \\
78\end{array}$} & \multirow{2}{*}{$\begin{array}{c}\begin{array}{c}\text { Type of } \\
\text { area }\end{array} \\
\text { Urban }\end{array}$} & \multirow{2}{*}{$\frac{\begin{array}{c}\text { Method of } \\
\text { selection }\end{array}}{\text { Day Nursery and Child Welfare Centre. }}$} \\
\hline Aylesbury & . & . & A. A. Moncrieff & . & & & \\
\hline Birmingham . & . & $\cdots$ & L. G. Parsons & .. & 484 & Urban & $\begin{array}{l}\text { Out-patients without disease. Welfare } \\
\text { Centres Health Visitors list (every } \\
\text { 40th): good response. }\end{array}$ \\
\hline Bristol & . & . & C. B. Perry.. & . & 243 & Urban & $\begin{array}{l}\text { Every } 20 \text { th from birth register. Eighty } \\
\text { per cent. attendance. }\end{array}$ \\
\hline Cardiff & . & . & A. G. Watkins & . & 269 & Urban & Infant Welfare Centres. \\
\hline $\begin{array}{l}\text { Hackney (Lor } \\
\text { Hammersmith } \\
\text { (London). }\end{array}$ & $\begin{array}{l}\text { ndon) } \\
\text { h }\end{array}$ & .. & C. Potter .. & & $\begin{array}{c}125+222 \\
215\end{array}$ & Urban & $\left\{\begin{array}{l}\text { Out-patients. } \\
\text { Welfare Centres. }\end{array}\right.$ \\
\hline Leeds . . & . & . & C. W. Vining & .. & 146 & $\begin{array}{l}\text { Urban } \\
\text { (mostly) }\end{array}$ & $\begin{array}{l}50 \text { per cent. unselected Welfare Centres. } \\
50 \text { per cent. unselected hospital cases. }\end{array}$ \\
\hline Leicester & . & . & J. V. Braithwaite & .. & 96 & Urban & $\begin{array}{l}\text { Routine attendances at Welfare Centres } \\
\text { and children normally left in a day } \\
\text { nursery. }\end{array}$ \\
\hline $\begin{array}{l}\text { Lincoln (parts } \\
\text { even). }\end{array}$ & s of Kes & & R. Ellis $\quad \ldots$ & . & 200 & $\begin{array}{l}\frac{1}{3} \text { Urban } \\
\frac{2}{3} \text { Rural }\end{array}$ & $\begin{array}{l}\text { A substantial portion of the eligible age } \\
\text { group (see page } 45 \text { ). }\end{array}$ \\
\hline Liverpool & . & $\cdots$ & N. Capon .. & . & 284 & Urban & $\begin{array}{l}\text { All routine attendances at Welfare } \\
\text { Centres. }\end{array}$ \\
\hline Manchester . & $\cdots$ & . & C. Chisholm & . & 218 & Urban & $\begin{array}{l}\text { Two groups, one from the inner area of } \\
\text { Manchester, the other from the outer } \\
\text { verges of the suburbs. Cases were } \\
\text { 'rounded up' by the Health Visitors } \\
\text { of the district and the children were } \\
\text { partly those attending Welfare Centres } \\
\text { and partly those who had never at- } \\
\text { tended a Centre. }\end{array}$ \\
\hline Newcastle & $\cdots$ & $\cdots$ & J. C. Spence & . & 218 & Urban & $\begin{array}{l}10 \text { per cent. picked in Social Class I. } \\
80 \text { per cent. Welfare Centres (artisan). } \\
10 \text { per cent. Casual O.P. (poorest } \\
\text { class). }\end{array}$ \\
\hline St. Albans & . & . & A. W. Franklin & $\cdots$ & 200 & Urban & Normal babies at Welfare Centre. \\
\hline
\end{tabular}


ENGLAND AND WALES-continued

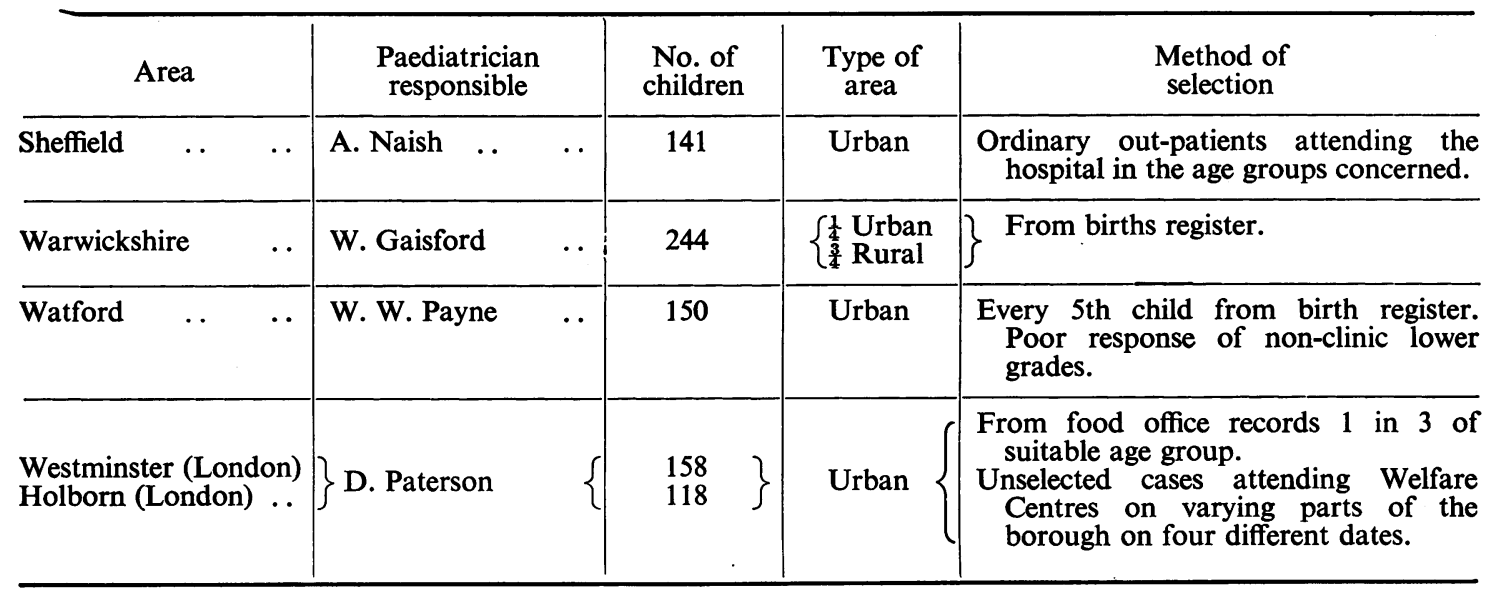

SCOTLAND

\begin{tabular}{|c|c|c|c|c|c|c|c|}
\hline Aberdeen & $\cdots$ & . & $\begin{array}{cc}\text { J. Craig } \quad \cdots \\
\\
. & \end{array}$ & . & 321 & Urban & $\begin{array}{l}\text { Every fourth case in the birth register } \\
\text { was sent for, but there were quite a } \\
\text { number of defaulters. Some of the } \\
\text { defaulters were from the poorest } \\
\text { districts, therefore some cases of } \\
\text { active rickets may have been missed. }\end{array}$ \\
\hline Edinburgh & $\cdots$ & .. & T. Y. Finlay & .. & 220 & Urban & $\begin{array}{l}20 \text { cases were taken from each of the } \\
\text { Health Visitors boxes of schedules and } \\
\text { the method was to take at random } \\
\text { five each of children aged three } \\
\text { months, six months, one year and } \\
\text { eighteen months. The survey, there- } \\
\text { fore, covers the whole area of the City } \\
\text { of Edinburgh, that is good and bad } \\
\text { housing areas. }\end{array}$ \\
\hline Glasgow & . & . & S. G. Graham & . & 700 & Urban & $\begin{array}{l}\text { Chosen from all Child Welfare Centres } \\
\text { at random and considered to be 'a } \\
\text { very good cross-section of the Glasgow } \\
\text { child population at present.' }\end{array}$ \\
\hline
\end{tabular}

NORTHERN IRELAND AND EIRE

\begin{tabular}{|c|c|c|c|c|c|c|c|}
\hline Belfast & . & .. & F. M. B. Allen & .. & ${ }^{71}$ & Urban & $\begin{array}{l}\text { All cases were out-patients attending the } \\
\text { hospital, the vast majority of which } \\
\text { were from medical out-patients, a very } \\
\text { small number indeed from surgical } \\
\text { out-patients. }\end{array}$ \\
\hline Dublin & & .. & W. R. F. Collis & $\ldots$ & 200 & Urban & $\begin{array}{l}118 \text { were general out-patients attending } \\
\text { the Children's Hospitals, and } 82 \text { were } \\
\text { from seven Welfare Centres in the City } \\
\text { of Dublin. }\end{array}$ \\
\hline
\end{tabular}




\section{APPENDIX 2 \\ SPECIMEN QUESTIONNAIRE \\ BRITISH PAEDIATRIC ASSOCIATION}

Questionnaire on Rickets in Children between Three and Eighteen Months

(To be filled up by the Paediatrician in charge, for each child who is $\mathrm{x}$-rayed)

Name

Address

Date of Birth.

Date of $\mathrm{x}$-Ray Examination

Method of Feeding: Breast or Breast and Bottle or Bottle.

(Strike out words not applicable.)

If BREAST FED, for how long?.

If BoTtLE, what sort of Milk or Milk Preparation?

What is the Feeding at present?

Cod-Liver Oil and/or Vitamin ' D’ Additions:

Was any Cod-Liver Oil or other preparation given? Yes or No

(Strike out word not applicable.)

If YES, give the following particulars:-

\begin{tabular}{|c|c|c|c|c|c|c|}
\hline \multirow{2}{*}{\multicolumn{3}{|c|}{ Preparation used }} & \multirow{2}{*}{$\begin{array}{l}\text { In bottle (B) or } \\
\text { by spoon (S) }\end{array}$} & \multirow{2}{*}{$\begin{array}{l}\text { Age in months } \\
\text { when begun }\end{array}$} & \multicolumn{2}{|c|}{ (Give I.U. if possible) } \\
\hline & & & & & Initial daily dose & Present daily dose \\
\hline \multicolumn{7}{|c|}{ Cod-Liver Oil-Plain .. } \\
\hline Emulsion & . & . & & & & \\
\hline Other Preparations & .. & .. & & & & \\
\hline
\end{tabular}

Other Prophylaxis: Exposure to Sunshine (a) Natural. Yes or No.

(b) Artificial. Yes or No.

If YES, how long before present date in weeks?

Clinical Evidence of Rickets:

Is Rickets present or not? YES or No.

(This refers to active Rickets at the present time.)

Has Rickets ever been present? YES or No.

(a) Anterior Fontanelle: Closed. If OPEN, size

(b) Craniotabes: Absent. Doubtful. Present

(c) Enlarged Epiphyses (Wrists). Absent. Doubtful. Present.

(d) Enlarged Costo-Chondral Junctions: Absent. Doubtful. Present.

(e) Age of Walking

(f) No. of teeth.

Signed

Date

X-Ray Examination: (To be filled up after examination by the Radiological Committee.)

(A.P. One Wrist)

Rickets Present: Yes oR No.

Whether Active or Old (Healed).

(Strike out words which do not apply.)

Signed

Radiologist.

Date. 


\section{APPENDIX 3}

The following particulars of surface soils and underlying formation in the areas surveyed (parts of Kesteven) has kindly been supplied by Mr. H. T. Cranfield, Advisory Chemist, Midland Agricultural College, Loughborough.

Fen and Fen Border

$$
\text { Villages }
$$

\begin{tabular}{|c|c|c|}
\hline Anwick & $\cdots$ & \\
\hline Digby & . & \\
\hline Dorring & & $\cdots$ \\
\hline Great $\mathbf{H}$ & & • \\
\hline Hecking & & • \\
\hline Helpring & & - \\
\hline Rusking & & $\cdots$ \\
\hline Scopwic & . & . \\
\hline
\end{tabular}

Boulder Clay, Oxford Clay, bordering fen ..

. Cornbrash, Oxford Clay

- Cornbrash, Oxford Clay

. Glacial Sands and Gravels with Boulder Clay

- Glacial Sands and Gravels with Boulder Clay

.. Glacial Sands and Gravels with Boulder Clay

. River Gravels mainly adjoining Oxford Clay

. Lincs. Limeston?, Estuarine Clay and Great Oolite
Formation Underlying

. Probably Oolitic.

.. Oolitic.

. Oolitia

.. Probably Oolitic.

. Probably Oolitic.

.. Probably Oolitic.

. Oolitic.

.. Oolitic.

\section{Heath Villages}

Ancaster

Ashby-de-la-Launde

Brauncewell

Leasingham

Rauceby

Sudbrook

Wilsford

Sleaford
. Lincs. Limestone, River Gravels, Alluvium . .

. $\quad$. $\quad$.. $\quad$ Oolitic.

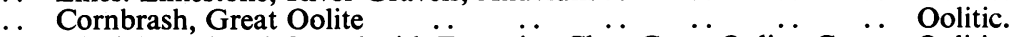

.. Glacial Sand and Gravel with Estuarine Clay, Great Oolite, Corn- Oolitic. brash and Lincs. Limestone surrounding.

. Cornbrash (mainly) with Great Oolite and Estuarine Clay .. Oolitic.

.. $\quad$.. $\quad$ Cornbrash, Lincs. Limestone, Estuarine Clay, Great Oolite $\quad$.. Oolitic.

$\cdots$

. River Gravels, Upper Lias Clay

- Lincs. Limestone, River Gravels

.. River Gravels, Cornbrash, Oxford Clay

.. Oolitic.

.. Oolitic.

. Probably Oolitic. 